Bulletin d'études orientales

\title{
Cresting on Arrows from the Citadel of Damascus
}

David C. Nicolle

\section{(2) OpenEdition \\ Journals}

Electronic version

URL: http://journals.openedition.org/beo/5018

DOI: 10.4000/beo.5018

ISSN: 2077-4079

Publisher

Presses de l'Institut français du Proche-Orient

\section{Printed version}

Date of publication: 1 April 2017

Number of pages: 247-286

ISBN: 978-2-35159-731-6

ISSN: 0253-1623

Electronic reference

David C. Nicolle, "Cresting on Arrows from the Citadel of Damascus", Bulletin d'études orientales

[Online], LXV | 2017, Online since 01 April 2019, connection on 06 January 2021. URL: http://

journals.openedition.org/beo/5018; DOI: https://doi.org/10.4000/beo.5018 


\title{
Cresting on Arrows from the Citadel of Damascus
}

\author{
David C. NICOLLE
}

\begin{abstract}
A substantial number of arrow fragments were found during an excavation in the Citadel of Damascus. They date from the very late Mamlūk and probably very early Ottoman periods (late 15th to early 16th centuries CE). The arrows are typical of this period and of TurcoIslamic archery in general, having similarities with fragmentary and occasionally complete arrows from Central and Inner Asia, especially where their nocks are concerned. One of the most distinctive features of the Damascus Citadel arrow fragments is their cresting (painted colouring around, within, and next to the nocks). A variety of patterns can be identified. These can be grouped according to colour, number and size of rings. Although cresting is barely mentioned in medieval written texts, one may to assume that it was primarily functional and provided a means of identifying the arrows. What remains unclear is the purpose of such identification, whether it concerned ownership of an arrow or was to identify a type of arrow and arrowhead. A substantial number of arrow fragments with arrowheads attached were also found in the Citadel of Damascus, but are too fragmentary for a connection to be made between types of arrowhead and the different designs of cresting.
\end{abstract}

Keywords: Arrow nock, cresting, fletchings, furūsiyya, Hazānat al-Silāḥ, maydān.

Résumé : Lors de fouilles dans la citadelle de Damas, un nombre important de fragments de flèches a été mis au jour. Ils sont probablement datables de la toute fin de la période mamelouke et du début des Ottomans (fin $\mathrm{XV}^{\mathrm{e}}$-début $\mathrm{XVI}^{\mathrm{e}} \mathrm{s}$.). Les flèches appartiennent typiquement à cette période et sont représentatives de l'archerie turco-islamique en général, montrant des similitudes avec des fragments et parfois des flèches complètes d'Asie centrale et intérieure, particulièrement en ce qui concerne leur encoche. L'une des caractéristiques des fragments trouvés dans la citadelle de Damas est leur décoration : elle prend la forme d'une coloration autour, à l'intérieur et à côté des encoches. Divers modèles ont pu être identifiés en fonction de la couleur, du nombre et de la taille des anneaux. Bien que ces décorations soient à peine mentionnées dans les sources médiévales, on peut supposer qu'elles furent principalement fonctionnelles et permettaient d'identifier des types de flèches. On s'interroge toutefois sur les raisons d'une telle identification : s'agissait-il d'un marquage propre à leur propriétaire où était-ce le moyen d'identifier des types de flèches en fonction de leur pointe? À Damas, des 
fragments de flèches avec pointes ont également été trouvés sans qu'il soit possible de mettre en relation des types de flèche avec les différents modèles de décoration.

Mots-clés : flèche, encoche, décorations, empennage, furūsiyya, Hazānat al-Silāh, maydān.

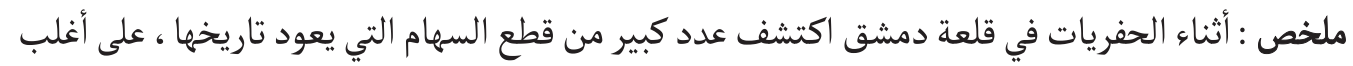

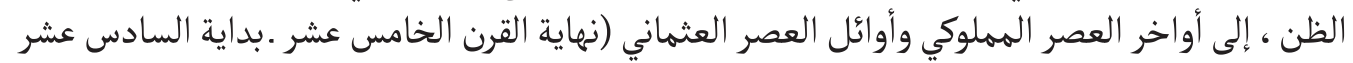

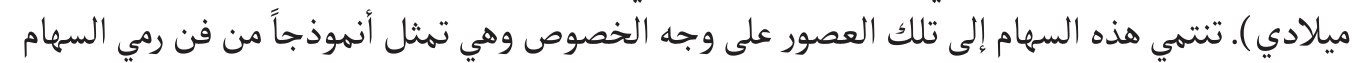

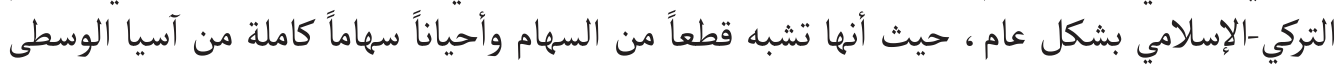

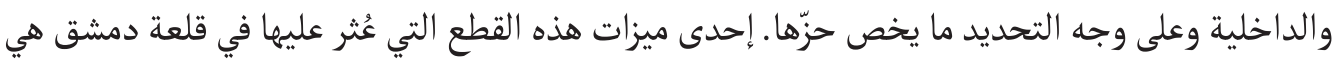

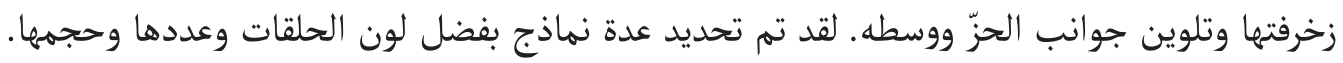

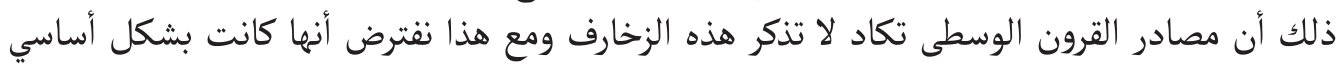

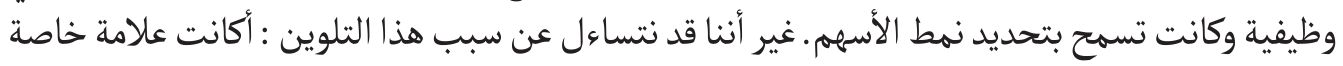

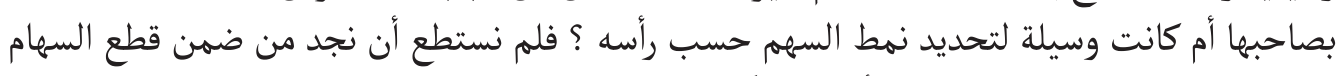
التي عُثر عليها في دمشق وهي ذات رأس علاقةً تربط بين نمط السهم ومختلف نماذج الزخرفة. الكلمات المحوريّة : سهم ، حزّ ، زخرفات ، تريش سهم ، فروسية ، خزانات السلاح ، الهيدان. 


\section{Introduction}

The article concerns a specific aspect of a substantial number of arrow fragments found during an excavation in the Citadel of Damascus, but which was only briefly discussed in the author's book on the military finds from this excavation (NICOLLE 2011). It begins by looking at the historical context of these finds, and at documentary sources related to it, before reviewing evidence concerning arrows in later medieval Islamic and Central Asian cultures. This is followed by a detailed description of the arrow fragments, especially the different types of nocks present amongst these finds. However, the primary focus of the article is the painted patterns, primarily consisting of rings, within and around the nocks and around the rearmost parts of many arrow-shafts. These decorations or crestings are grouped according to colour and the number and size of rings, after which the preponderance of certain colours and ring-patterns are discussed. Next the article looks at comparative documentary and archaeological evidence from the Islamic world and from some militarily related neighbouring cultures. The article concludes with an attempt to draw conclusion concerning the purpose of such coloured cresting within the cultural context of the late medieval Islamic world.

\section{The Finds}

The finds of largely late Mamlūk military and related material uncovered within a building in the south-western corner of the Citadel of Damascus (CD5), by a Franco-Syrian archaeological mission, were published by the Institut Français du Proche-Orient in 2011 (NiCOLLE 2011). Here the abundance of broken arrows and crossbow bolts, plus a tiny number of complete missiles (though lacking their flights) was noted, and their main features described in some detail (NICOLLE 2011, p. 135-193, 297-320, 365-367). However, it was only possible to include passing reference to the remarkable variety of colours and lines, or cresting, around and occasionally within the nocks of some fragments. Although most of the arrow fragments had no markings, red was the predominant colour where such markings could still be indentified. Photographs 1 and 2 show only a fraction of the total number of arrow fragments which were found in CD5, but do indicate how the degree or density of surviving colour varied between such fragments.

Quite why an abundance of broken arrows should have been abandoned is still unknown. Yet this could have a bearing upon the reasons why some were decorated or identified by various patterns of painted or drawn rings around their nocks and the rear of their shafts. Had chamber CD5 been a workshop or part of an arsenal, or perhaps both? Or might the entire cache of military material have simply been dumped there as redundant? Sophie Berthier, who directed the excavations, suggested that the room in which most of these objects were found had at one time been a workshop. Here broken or otherwise discarded military artifacts may have been stored, presumably to supply spare parts, otherwise useful material, or perhaps for future repair. At some subsequent date 
this material became redundant. It was then largely swept into light-wells in the floor of the upper chamber which had, in turn, been sealed off at their lower ends. These sealed light-wells thus formed convenient spaces into which rubbish could be thrown before their upper ends were also sealed by the laying of a new floor across the upstairs chamber.

During the Ayyūbid and Mamlūk periods, the upstairs chamber and perhaps the entire building may have served as one of those Hazānat al-Silāh (Treasuries of Arms) which were characteristic of medieval Islamic civilization ${ }^{1}$. Here it is worth drawing attention to an anonymous text known as the Hazānat al-Silāh which described the contents of such arsenals in Ayyūbid and Mamlūk territory (Anon., Hazānat al-Silāh. 1978). For example, large sections of the first part of that work, concerning weaponry, dealt with sihäm arrows. It was preceded by sections dealing with swords and spears, and was followed by a section dealing with defensive equipment such as armour.

Elements of a Mamlūk arsenal clearly survived within the Citadel of Damascus following the Ottoman conquest, and although such objects may have been regarded as redundant, they had not yet been sealed within an old lightwell. Some of this material still existed in 1722, when it was the subject of an inventory drawn up on orders from the Sultan's government (Ibn Kannān 1994) ${ }^{2}$. This inventory recorded that, although the cache includes nuššăb arrows, the splendour and value of several pieces, plus the fact that some were specifically associated with the Mamlūk Sultan Baybays I, attracted the Ottoman bureaucrats' particular attention. Nevertheless, an association with Baybars means that this cache was more likely to be linked to a different and as yet largely unpublished hoard from Tower 4 of the Citadel of Damascus, rather than with the material 'dumped' in building CD5. Indeed the military objects described by Ibn Kannān and those recently found in Tower 4 may have been the remains of a Mamlūk treasury which once celebrated the achievements of al-Malik al-Zāhir Baybars, rather than being the residue of an ordinary arsenal; still less a workshop.

Within the workshops of an ordinary Ottoman military arsenal it was - or it became standard practice to use parts of damaged arrows to make new arrows, as was also the case with other items of equipment. The reuse of arrowheads would seem obvious. However, P.E. Klopsteg, in his book on Turkish archery, refered to an early 19th century text, Excerpts from the Writings of the Archers by Kani which largely seemed to draw upon earlier Ottoman sources. This text stated that new arrows were made by reusing parts of old ones, seeming to suggest that more than just the heads were involved (KLOPSTEG 1947, p. 79-80).

1. For a discussion of the significance, function and location of such arsenals, see the section on "Arsenals, Arms Manufacture, Repair and Distribution", in NICOLLE 2011, p. 31-40.

2. I am grateful to Dr. Brigitte Marino for providing a translation of part of this text in 2008 . 


\section{Arrows in Islamic Cultures and in non-Islamic Central Asia}

While it was widely accepted that the heavier an arrow, the greater its power of penetration - all other factors being equal - it is also clear that the Turco-Mongol archery traditions of Inner and Central Asia, as well as those of the incresingly Turco-Mongol influenced medieval Middle East, did not rely upon heavy arrows in the way that, for example, medieval English archers did. Recent and more scientific studies of the ballistics of traditional Turkish archery have suggested that, as the mass of an arrow increases, so its initial velocity after release from the bow decreases. Conversely the lighter the arrow, the greater its initial velocity. However, the range of an arrow was effected by the fact that a missile with less mass was then slowed down by drag (air resistance during its trajectory or 'flight') to a greater extent than a missile with greater mass. Thus, given the same initial velocity, a heavier arrow flew further than a lighter arrow. Its range and velocity at the time of impact were, of course, also influenced by the arrow's shape (including the shape of the nock and rearmost part of the shaft around the nock), the smoothness of its surface, and its fletchings, all of which had a greater or lesser effect upon drag (BOIT 1991, p. 21-23). Arrows whose shafts are made entirely of reed, or of part wood part reed construction, absorb the vibration of release (caused by the arrow having to flex slightly as it bent around the bow) more quickly than arrow shafts made entirely of wood, and thus straightened out more quickly (MILLER 1985). Perhaps they also lost less energy as a result of consequent quivering throughout much of their flight.

Such factors were certainly known to medieval Muslim archers and were discussed in detail in medieval Islamic treatises on the art of archery. The archaeological evidence proves that the arrows shot by such Muslim archers were often very well made, though not invariably so. Their arrows also made use of a variety of nock-shapes, as seen in the abundant fragments from Damascus Citadel (CD5 and Tower 4) and elsewhere.

The sophistication of arrow manufacture in many parts of the medieval Islamic world was such that, where the finest arrows were concerned, experts stipulated the weight not only of the wooden shafts and iron or steel head, but also the feathered flights, the sinew bindings which strengthened various parts of the shaft, and even the tali or copal varnish. The latter was naturally the lightest of these elements and although the term is sometimes misleadingly translated as 'paint' it may have included the decorative or identifying marks which are the main subject of this article. The weight of these would, nevertheless, have been so insignificant that they could have had no influence upon the flight characteristics of the missile (LATHAM \& PATERSON 1965, p. 255-6 \& 255 n. 3).

Latham and Paterson looked in detail at the weights recommended in the 14th century Mamlūk Nihāyat al-Su'l treatise, which was itself largely based upon earlier texts. Their interpretation came to the conclusion that, according to the author of this text, the different weights of arrow, from the lightest at 304 grains avoirdupois (= 19.7 grams approx.) to the heaviest at 600 grains avoirdupois (=39 grams approx.), all incorporated just 4 grains avoirdupois (= 0.26 grams approx.) of țali (LATHAM \& PATERSON 1965, p. 261). However, when looking at medieval Mongol warfare in the Islamic middle East, J.M. Smith 
concluded that the normal war arrows of Middle Eastern armies were heavier than this, though still light by Western European standards. He stated that they were usually between approximately 42 grams (1.5 oz.) up to a maximum of 56 grams (2 oz) (SMITH 1996, p. 251-252).

It is also worth comparing the range of weights that the Nihayyat al-Su'l recommends for the nașl arrowhead, from 37 to 96 grains avoirdupois (=2.4 to 6.22 grams approx.) (SMITH 1996, p. 259-261), with that of the arrowheads found in CD5. The latter had, of course, lost a proportion of their weight as a result of corrosion, but those in moderately good condition nevertheless ranged from 3 to just under 9 grams ( $=46.3$ to 139 grains avoirdupois approx.) (NICOLLE 2011, p. 171-177). A few significantly heavier arrowheads of 12.27 grams (=189.35 grains avoirdupois approx.) were found elsewhere in the Citadel and but have been shot into the fortress from outside, by frame-mounted siege weapons during one of several assaults upon the Citadel of Damascus (NiCOLLE 2011, p. 171-177).

\section{Arrow Nocks in the CD5 finds}

Those parts of the arrow fragments from CD5 which have some form of coloured or striped identification consist of the following elements: the fūq or nock, the šarh $\bar{a}$ al-fūq or two sides of the nock which, with a few exceptions, are broader than the haqw or lihāz rear part of the shaft to which the fletchings are attached and which might also be partially or wholely coloured, plus the rearmost part of the matn or broader middle part of the qidh or shaft. Some of the arrow fragments incorporated an utra binding to strengthen the nock, though most no longer did so, and where this was present on painted arrows the paint went over such binding.

For the purposes of this study, the styles or shapes of nocks on the CD5 arrow fragments have been differentiated as follows:

Nock Type A1: Incorporating a bulge around the nock (as do types B and C) but having a rounded profile or outline, without any angle or ridge. This type is by far the most common form, although in a small number of cases the bulge around the nock was also elongated. Arrow shafts which survive with sufficient length to be measured have a maximum shaft thickness ranging from 8 to $9 \mathrm{~mm}$. The waist or narrowest part of the shaft ahead of the nock ranges from 6 to $8 \mathrm{~mm}$ while the maximum thickness around the nock ranges from 8 to $11 \mathrm{~mm}$. In the majority of these better preserved examples the maximum thickness around the shaft is the same as the maximum thickness around the nock. However, in a very few cases the thickness around the nock is from 0.5 to $2 \mathrm{~mm}$. greater than the maximum thickness of the shaft. In only one example was the thickness around the nock less than that of the maximum thickness of the shaft; these measurements being 8.5 and $9 \mathrm{~mm}$. respectively. The nocks themselves went from the butt-end of the arrow as far as the maximum thickness around the nock. On only two of the arrows with colouring around the rear parts of their shafts did sufficient evidence of their fletching survive to be measured. In both cases the glued edges of these fletching were $118 \mathrm{~mm}$. long, which was the same as that on sufficiently well preserved but unpainted arrows. 
Nock Type A2: In just one example of a particularly finely made arrow, the bulge around the nock again had a rounded profile or outline but was particularly elongated and may originally have been asymmetrical. However, this latter feature could have been the result of damage or wear. The nock itself was also longer than usual (from CD 5.2.421.(12).6).

Nock Type B: In this limited number of arrow butts and nocks, the profile of the narrow waist of the arrow curves abruptly outwards, then angles to run at a consistent width to the end of the shaft without narrowing again (from CD 5.2.300.(12).1a-e).

Nock Type C: In this limited number of arrow butts and nocks, the profile of the narrow waist of the arrow curves less abruptly outwards, then angles to run in a virtually straight but tapering manner to the end of the shaft (from CD 5.401.(12).12 and CD 5.411.(12).12).

Nock Type D: In this relatively rare type of arrow butt and nock there is no slendering to form a waist, so that the thickness of what remains of the arrow runs at a consistent $8 \mathrm{~mm}$ around the nock, along what would have been the waist in the more common forms of arrow, as far as the point where these arrows are broken.

Among the painted or otherwise marked arrow fragments from CD5 there appears to be a tendency for the more complex markings to be associated with the less common types of nock. However, this is certainly not obvious enough to be statistically valid. Nor are the numbers of coloured or marked arrow fragments from this one location sufficient to draw clear conclusions about such association. Nevertheless, none of the more unusual nock Types B, C and D had the most common form of plain red decoration, though one had plain red plus two black lines. All the others had white decoration plus more or less other colours or lines. Namely, the angled non-tapering Type B had white with one black line at the front of the colour, plus red inside the nock and on the flat end of the shaft (fig. 1/3, colour style $1 / f / 1)$. Angled and tapering Type $C$ had red plus two black lines near the front of the colour (fig. 2/8, colour style 1/b/3), or white with one black line at the front of the colour, plus red inside the nock and on the flat end of the shaft (fig. 3/15, colour style 1/f/1), or a narrow white band with brown paint as distinct from brown unpainted wood (fig. 5/29, colour style 2/f/1). Type D, which had no bulge around the nock, had white paint with one black line at the front of the colour, plus red inside the nock and on the flat end of the shaft (fig. 3/17, colour style $1 / f / 1$ ), or simply a white band on uncoloured wood (fig. 4/26, colour style $2 / \mathrm{d} / 1)$.

One might justifiably suggest that these unusual shapes of nock were not only rare, as is clear from their very limited numbers compared with the total number of fragments, but were generally associated with some other unusual feature. Perhaps they were long distance flight' arrows, or had more than usually specialized arrow-heads, or were associated with an élite group of archers either in terms of skill or rank. Or perhaps these arrows were simply of a later date than most of the others. In this context it is worth noting the white decoration or identification system on the Ottoman arrows preserved in Poznan.

The photographs of arrow fragments from CD5 also deserve comment. Photograph 2 (upper) shows just one typical example with simple red decoration. The wear and tear are plain to see. Indeed the red paint was so chipped and faded that it was necessary to electronically intensify the colour in this photograph to make it more visible. 
Photograph 2 (middle) highlights the difficulty in distinguishing between colour or line decoration and the remains of binding to strengthen the arrow's nock. This particular fragment also had a single black line around the rear of the shaft, ahead of the remains of the varnished binding. Photograph 2 (lower) brings together two of the most distinctive fragments: one with white paint plus a black band and red paint within the nock and on the flat end of the shaft, and the other with an unusual green colour. A third fragment shows the red painted nock on a fragment which is too short to know how far this red colour originally went along the shaft. The lowest fragment in this picture is actually the front rather than the rear of an arrow. Here can be seen the remains of deep red, varnished binding to strengthen the shaft around the hole where the tang of an arrowhead (not present) would have been inserted.

The following chart explains the system used in this article to identify and differentiate between the patterns of colours and lines or stripes (cresting) on many of the arrow fragments from the Citadel of Damascus building CD5.

Colourscheme 1: Single stripe (including a clearly defined band of unpainted wood)

1/a: Uncoloured wood (excluding black lines and colour inside the nock).

1/a/1: Uncoloured and without any other marking; this forming the great majority of the fragments (not numbered).

1/a/2: Uncoloured plus a black line.

$1 / \mathrm{a} / 3$; Uncoloured plus a red line.

1/a/4: Uncoloured plus red inside the nock.

1/b: Single colour red (excluding black lines).

1/b/1: Red only.

$1 / b / 2$ : Red plus a black line at the front of the colour.

$1 / \mathrm{b} / 3$ : Red plus two black lines near the front of the colour.

$1 / \mathrm{b} / 4$ : Red plus blue inside the nock.

1/b/5: Red plus red inside the nock.

$1 / \mathrm{c}$ : Single orange-pink colour.

1/c/1: Orange-pink plus a black line in front of the colour.

1/d: Single green colour.

1/d/1: Dark green only.

1/d/2: Mid-green only.

1/e: Single blue-green colour.

1/e/1: Single blue-green colour, plus red inside the nock and on the flat end of the shaft.

1/f: Single white colour.

1/f/1: White with a black line at the front of the colour, plus red inside the nock and at the flat end of the shaft.

1/f/2: White with a black line near the front of the colour.

$1 / \mathrm{f} / 3$ : White with a red line at the front of the colour, plus red inside the nock and on the flat end of the shaft. 
1/g: Single blue-black colour.

1/g/1: Blue-black, plus red inside the nock and on the flat end of the shaft.

Colourscheme 2: Two stripes (including enclosed "stripes" of uncoloured wood)

2/a: Orange and uncoloured wood.

2/a/1: Orange and uncoloured wood, plus a black line defining the front edge of the "wood".

2/b: Red and uncoloured wood.

2/b/1: Red and uncoloured wood, with a black line defining the front edge of the "wood"

2/b/2: Red and uncoloured wood, with two black lines defining the front edge of the "wood".

2/c: White and black.

2/c/1: White and black.

2/d: White and uncoloured wood.

2/d/1: White and uncoloured wood.

2/e: White and red

2/e/1: White and red.

2/e/2: White (very pale, or perhaps unpainted wood) and red, plus a black line at the front, and blue inside the nock

2/f: White and brown.

2/f/1: White and brown (paint, not unpainted wood).

Colourscheme 3: Three stripes (including enclosed "stripes" of uncoloured wood)

3/a: Black, uncoloured wood, and black.

3/a/1: Black, uncoloured wood, and black.

$3 / \mathrm{b}$ : Blue-green, white, and blue-green.

3/b/1: Blue-green, white, and blue-green, plus red inside the nock and on the flat end of the shaft.

3/c: Red, uncoloured wood, and red.

3/c/1: Red, uncoloured wood, and red.

3/c/2: Red, uncoloured wood, and red, plus a black line at front of the coloured area.

3/d: Red, white, and red.

$3 / \mathrm{d} / 1$ : Red, white, and red.

3/d/2: Red, white, and red, plus a black line at the front of the coloured area.

3/e: Red, white, and black.

3/e/1: Red, white, and black, plus a black line at the front of the coloured area. 3/e/2: Black, white, and black (note; the front edge of the coloured area is lost on this fragment). 
Colourscheme 4: Four stripes (including enclosed "stripes" of uncoloured wood)

4/a: Uncoloured wood, red, uncoloured wood, and red. 4/a/1: Uncoloured wood, red, uncoloured wood, and red, plus a black line at the front of the first uncoloured wood stripe.

4/b: Uncoloured wood, red, white, and red. 4/b/1: Uncoloured wood, red, white, and red, plus a black stripe at the front of a narrow uncoloured "stripe" of wood.

4/b/2: Uncoloured wood, red, white, and red, plus one black stripe at the front of the uncoloured wood stripe and another between the uncoloured wood and the first red stripe.

4/c: White, blue-black, white, and blue-black.

4/c/1: White, blue-black, white, and blue-black, plus red inside the nock and on the flat end of the shaft.

4/d: White, red, uncoloured wood, and red.

4/d/1: White, red, uncoloured wood, and red.

Colourscheme 5: Five stripes (including enclosed "stripes" of uncoloured wood)

5/a: Red, uncoloured wood, black, uncoloured wood, and black.

5/a/1: Red, uncoloured wood, black, uncoloured wood, and black (note; the red stripe is a considerable way along the shaft, separated from the other coloured stripes by a broad area of uncoloured wood).

Colourscheme 6: Fourteen stripes (including enclosed "stripes" of uncoloured wood)

6/a: Uncoloured wood, red, white, red, white, red, white, red, white, red, white, red, white, and red.

6/a/1: Uncoloured wood, red, white, red, white, red, white, red, white, red, white, red, white, and red, plus a black stripe at the front of the stripe of uncoloured wood.

\section{Comparative Evidence}

Most studies of medieval Islamic texts concerning archery have focussed upon the bows and the arrowheads. There seems to have been less interest in other aspects of the arrows and much the same has been true of archaeological studies of ancient and medieval archery. Of course, it is the iron arrowheads which tend to endure, but even when arrows survive, either complete or fragmentary, small interest seems to have been shown in their decorative schemes. This is despite evidence that such markings might reflect cultural indentification, aesthetic values, or the possibility that certain markings might have had a practical function - namely to identify the arrows in question.

Where medieval Islamic arrows are concerned, the terminology is still far from clear and its meanings may well have altered slightly over time, or amongst different peoples or lingusitic groups, or between different regions. For example is has been suggested that the 
word sahm originally referred to an arrow wholely or partially of reed, but sahm seemed to refer to an arrow of 'hard wood' during Mamlūk times. Meanwhile nabl is understood to have referred to the ordinary wooden arrow as used by Arabic speaking peoples while nuššăb is regarded as the equivalent Persian term. The nab wood traditionally used for arrows in the Arab world is identified as chadara velutina, of the genus grewia, which is a type of tree related to European limes. It has been more specifically identified as grewia tenax which grows in India, parts of Africa and Arabia ${ }^{3}$.

However, within the medieval eastern Iranian world and Transoxania, arrows were traditionally made of halanğ or hadang wood which is normally translated as poplar. Arrows and bows of halang were, for example, one of the main products of the Transoxanian province of Shash (around present-day Tashkent) during the 10th century (Anon., Hudūd al 'Ālam 1937, p. 118). Bìd or willow was another wood favoured for arrows in the Iranian speaking regions. For example the 13th century scholar Fakhr-i Mudabbir (Muhammad b. Manșūr Faḩr al-Dīn Mubārakūšāh) stated that hadang (poplar) arrows were too heavy for great range or flight shooting whereas bìd (willow) arrows offered greater range but were more slender and broke more easily. He further insisted that the longest range was achieved using arrows of kilk (reed) though these need to be well matured, dried and straightened in a mould (Mubārakūšāh 1974, p. 94; Mubārakūšāh 1969, folio 244). The remarkable text by Fakhr-i Mudabbir has yet to be studied in depth and, as far as I am aware, the earlier military or furussiyya texts upon which he presumably relied, and the earlier archery traditions which he clearly reflected, have yet to be conclusively identified.

shooting flimsier flight arrows over long distance took great skill, as the arrow could break if it did not leave the bow cleanly and as it curved or bent around the grip. Even when loosed correctly it would, in a military context, suffer the disadvantages of less accuracy and less impact. Indeed, by the later medieval period long-range flight shooting was more of a sporting skill than a stricly military one, at least amongst the professional as distinct from tribal warriors of the Islamic world (LATHAM 1968, p. 242-243). Close ranger archery was of far greater importance to the fully trained professional färis cavalryman; be he a mamlük or a free-born warrior. This was clearly the case by the later medieval period and had probably always been so.

J.M. Smith concluded that although normal medieval Middle Eastern arrows were light by European standards, they were designed to be shot at close range, those of horsemen being lighter than those of infantry who would, tactically speaking, normally want to keep enemy cavalry at a distance (SMITH 1996, p. 251-252). The manual of archery attributed to the Mamlūk military expert Ṭaybugāa al-Ašrafî al-Baklamīšĩ al-Yunānī, written in 1368 AD, is very specific where the shapes of the three basic forms of arrow shaft are concerned: the 'candle-form' being thicker towards the head, the 'barley grain' which swelled towards the centre of its shaft, and the 'straight hewn' which had the same breadth through its entire

3. I am grateful to the Arbicultural Association's Advisory Service and the Royal Botanical Gardens Information Service for this information, provovided to me in May 1992. 
length (J.D. LATHAM \& W.F. PATERSON 1970, p. 24). However, the author writes very little about the nock (Taybuḡa uses the early Turkish word kāz meaning 'something concave' or an 'indentation'; a term probably related to the Arabic word hazz meaning an 'incision', a 'notch', or one of the nocks on the arm of the bow to hold the loops of the bowstring). He merely states that the nock should be of medium size, neither too small nor too big (J.D. LATHAM \& W.F. PATERSON 1970, p. 27). Furthermore, Ṭaybugāa al-Ašrafī wrote nothing about any form of painted decoration or identification markings.

The archaeological evidence proves considerably more useful than the documentary. It is also relatively abundant, with fragments of arrows surviving in dry or particularly cold conditions across a substantial part of Asia and the Middle East. In Palestine, for example, composite arrow fragments of partially reed, partially wooden construction were found in the context of the 1st century AD Jewish defence of Masada (COULSTON 1985, p. 267). It was also suggested that, when compared to official Roman mass production systems, more personalized arrows "appropiate to the archer's draw length.... would have been possible in the Levantine 'private sector' of urban workshops" (COULSTON 1985, p. 269).

Elsewhere and somewhat later in the Middle East, abundant arrow fragments were found in the 3rd century AD Roman frontier fortress at Dura Europos, overlooking Syria's Euphrates valley. No arrows were complete but their construction was essentially uniform, consisting of a reed cane with a wooden forepart inserted into the cane and projecting from it. The wood of one tested fragment was identified as tamerisk and the joint between wood and reed was bound with fibre to stop the cane splitting. As Simon James pointed out, the addition of a forepart of a harder material was common practice across much of the world and had been so since ancient times in the Middle East. It would continue into the medieval period. More significantly, in the context of the present study, James noted that; "Red, black and sometimes white or pink painted decoration (the 'cresting') was then added before fletching" (JAMES 2004, p. 196). Simon James then described the cresting on six arrow fragments from Dura Europos as follows (JAMES 2004, p. 207-208) ${ }^{4}$ :

733 - "Before the fletching was added, the shaft was given painted decoration (the 'cresting').

This consisted of a simple broad band of red paint, $25 \mathrm{~mm}$ wide".

734 - "The last $18 \mathrm{~mm}$ of the shaft were painted black, overlaying the nock and anti-split binding. This was bounded by a $4 \mathrm{~mm}$ wide red band. A large white spot was painted on each wing of the nock, and a smaller red one within, making an 'eye' About $4 \mathrm{~mm}$ inside the ends of the vanes is a $1 \mathrm{~mm}$ wide black band. Next to it is a $5 \mathrm{~mm}$ diameter red spot between each vane". (figure 8/3)

735 - "The anti-split binding around the nock stretches $30 \mathrm{~mm}$ along the shaft and is totally covered in paint. Black covers the last $24 \mathrm{~mm}$, and is bounded by a band of red $11 \mathrm{~mm}$ wide. The wings of the nock each bear a white spot, $11 \mathrm{~mm}$ long, and on that a red spot c.7 mm long, The inside of the nock is also painted red. Towards the leading edge of the vanes are a narrow

4. He uses his own numbering system which was different from that of the Yale University Art Gallery where these objects are stored. 
black band and red spots identical to those on 734.... (the) vanes.... were of course added after the cresting". (figure 8/4)

736 - "The cresting is again red and black, but of a different type. The wings and interior of the nock are red, except for the outsides of the tips which are black. A $2 \mathrm{~mm}$ wide red band surrounds the shaft $46 \mathrm{~mm}$ from the end, and another, $20 \mathrm{~mm}$ wide, starts $94 \mathrm{~mm}$ from the end". (figure 8/5)

737 - "The cresting consists simply of a broad band of black pigment, starting $92 \mathrm{~mm}$ from the end, and continuing for $51 \mathrm{~mm}$, followed by a pink band. The width of the latter is unknown as the shaft is snapped, but it was at least $15 \mathrm{~mm}$ ". (figure 8/6)

738 - "The last $173 \mathrm{~mm}$ of the shaft are painted. Starting at the nock, there is $46 \mathrm{~mm}$ of very pale pink, then $82 \mathrm{~mm}$ of black, followed by another $45 \mathrm{~mm}$ of the pink". (figure 8/7)

739 - "The nock wings were painted solid deep red" (not illustrated).

There was also some painted decoration on arrows found in the same cemetary as the Qum Darya bow, not far from Dura Europos (COULSTON 1985, p. 268; GARBSCH 1978, p. 33-34).

Unfortunately most Russian archaeological reports and studies concerning arrows excavated in Central and Inner Asia have only been published with black and white line illustrations, and mostly without photographs. In such drawings it is difficult to distinguish between the remnants of various forms of binding around the nock and the remnants of painted decorations or identification marks - namely cresting. The texts of such reports do, however, sometimes mention decoration and the colours used. For example, archery equipment excavated from early Iron Age Scythian sites in Tuva in association with the remains of a simple (that is a self or non-composite) bow included ten arrows. Sadly it seemed that their rear ends or tail units were missing except in one case where a nock remained. Some had red decoration, but whether all the markings were in red (as shown in figure 8/8-9) remains uncertain. The authors also pointed out that this archery equipment had almost no similarities with the archery equipment of subsequent Turkish and Mongol peoples who inhabited the same area. This was most obviously in the Iron Age Scythians' use of the simple rather than composite bow (SEMENOV \& KILUNOVSKAYA 1990, p. 48). Somewhat later arrows associated with the Kokelski people of southern Siberia, dating from the 2 nd to 5 th centuries $\mathrm{AD}$, also indicate some form of decoration or identification in the form of narrow bands or stripes around the shafts of the arrows. This was placed both ahead of the flights and behind them. As far as I am aware, the best source for decorative or 'crested' arrows from the fortified frontier regions of the Chinese Empire remains the works of Aurel Stein (STEIN 1921, 1928).

of more immediate significance in understanding the development of archery in the medieval Islamic world are the 8th century arrows found during excavations of Mug-tepe. This site has been identified as the palace of Kasan, the main castle of Arslan Tarkan, the ruler of Fargana (now largely in the easternmost province of Uzbekistan but also extending into Kyrgyzstan and Tajikstan) during a period when the north-eastern frontier 
of Islam was stabilizing around Fargana. This region would itself soon be absorbed into medieval Islamic civilization. The dominant Turks of this highly developed and urbanized region were of Karluk origin, some being Buddhists. The arrows from the 'Castle of Mug' include the all wooden type and the type made partially of wood and partially of reed. In most cases the rear had binding from 1 to $8 \mathrm{cms}$. from the rear end (BENTOVICH 1958, p. 360-361). Once again most of the published photographs were monochrome but I have privately been shown one colour photograph which shows an arrow fragment having clearly defined red and what appeared to be black decoration or cresting. I.B. Bentovich, the Soviet archaeologist who wrote a brief account of this site and its arrows, described the cresting as consisting of crosswise stripes of a width up to 2 to $3 \mathrm{cms}$, in black, yellow or red. The stripes were separated by a narrow black stripe. In some cases it was possible to trace a simple design consisting of stripes and dots while there were also some more intricate designs, including what Bentovich described as a sort of 'eye' pattern or motif (BENTOVICH 1958, p. 360-361).

The presence of apparent 'eye' motifs brings to mind arrow fragments from pre-Islamic late Roman Syria (see above), as well as from medieval Islamic Palestine and Egypt (see below). Furthermore, these arrows from Mug-Tepe include a significant number with parallel sided nocks which otherwise seemed very rare amongst the peoples of Central Asia. Perhaps this form of nock was characteristic of settled peoples who were more Iranian than Turkish in their military traditions and technology. Perhaps they even belonged to Muslim troops who, by the time of the invasion and conquest of Fargana, included significant numbers of Iranians and other non-Arab troops within their ranks. Or perhaps these particular arrows were for long distance flight shooting during training rather than war, as may have been the case with comparable arrows found in the Citadel of Damascus. Suffice to say that military artefacts from Fargana stem from a period, culture and location which already had a close association with early Islamic frontier armies and which would subsequently have a profound influence upon most aspects of Islamic military technology, not least archery and its training.

Again the early Islamic written evidence is of very limited help where cresting or other forms of decoration are concerned. For example, writing in the 13th century Magrib or far west of the Islamic world where earlier Arab-Islamic traditions of infantry archery survived after they had virtually disappeared in the Middle East, Abū Muhammad Ǧamāl al-Dīn cAbd Allāh Ibn Maymūn dedicated a significant number of lines to fletching (FARIS \& ELMER 1945, p. 110-111). He was similarly detailed concerning nocks and of ways of avoiding them breaking under the strain of loosing an arrow around the belly of a bow (FARIS \& ELMER 1945, p. 71) and stating that "the sinew whipped around the base of the nock is called the ring (utrah)" (FARIS \& ELMER 1945, p. 103). Even so, he still made no comment where cresting was concerned.

I am not aware of surviving medieval arrow fragments from the Magrib. However, such fragments have been found in Egypt though as yet only in very small numbers. They include those from the excavated late 12th century fortress of Șadr, better known as 
Qala'at al-Jindī (Gindī), in Egypt's Sinai peninsula. Fortunately they have been published in colour and probably date from the very late $12^{\text {th }}$ or early 13 th centuries. Though the castle was supposedly almost abandoned following Saladin's liberation of Jerusalem in 1187 AD, it seems likely that Șadr was either continuously garrisoned at a minimal level, or was re-garrisoned during the threatened Mongol invasions of the 13th century late Ayyübid and early Mamlūk decades.

If this was indeed the case, then it is not surprising that one of the largest arrow fragments has closer parallels with fragments from Montfort Castle than with fragments from Damascus. Such similarity is most obvious in arrows sharing what has been described as green and red 'eye' or 'snake' motifs. Though identified by A. Zouache, wrongly in my opinion, as crossbow bolts (ZOUACHE in MOUTON 2010, vol. 1, p. 208);

Three shafts are painted red and two have traces which seem to have been blue (which is more likely than black). This is not rare, having been seen on the shafts from Montfort, which had transverse bands, alternately blue and red, as decoration; in addition to this they include a talismanic eye.

of the two fragments from Șadr which are painted red, one also has the unusual non-bulbous nock.

Meanwhile the Turkish Book of Dede Korkut, which had probably been written down in $13^{\text {th }}$ or early 14 th century Turkey or Azerbayjan, described the wood from which arrows were made, and sometimes mentioned the colour of an arrow's flights. The colours of other military equipment are similarly described, but there were no references to the colours of an arrow's shaft (Anon., The Book of Dede Korkut 1974, passim).

Other arrow fragments from the Mamlūk era have been found, mostly in fortresses that have been properly excavated. However, not all Mamlūk castles or citadels proved equally fruitful, even when they were long occupied by substantial garrisons and were in locations where the climatic conditions seemed suitable for the preservation of fragile objects made of organic material. Even when arrow fragments were found, they did not necessarily include examples with decoration or cresting. Qașr Ibrīm in northern Nubia, for example, produced only undecorated arrow fragments. Perhaps this indicated that the low-grade troops sent to such unpopular postings did not indulge in the sort of intensive archery training that required carefully identified, high quality arrows (ADAMS 1996, p. 144).

Arrow fragments from the cave fortress of 'Āṣīl-Hadat in northern Lebanon are unusual in dating from a specific, well documented event - namely the Mamlük conquest of this Maronite Christian mountain refuge in 1283 AD. Nevertheless, it is unclear whether these arrows were shot into the caves by attackers who included Turkish tribal warriors as well as Mamlūk troopers, or had belonged to Christian defenders. Perhaps they came for both sides and in some cases may have been shot back and forth more than once. The Maronites of Mount Lebanon were themselves fine archers, as noted by the Crusader chronicler Jacques de Vitry (Jacques de Vitry 1612, chap. 77, p. 1093, in BAROUDY 2011, p. 206). The same was, of course, true of many other indigenous peoples of mountainous Lebanon and coastal Syria, both Christian and Muslim. 
Some of the arrows from ' ${ }^{\mathrm{A}} \bar{s} \overline{1}$ l-Hadat are rather crude missiles, including a complete arrow which, perhaps because it incorporated paper rather than feathered flights, has been incorrectly identified as a crossbow bolt. Paper flights are indeed more commonly associated with crossbow bolts, and as such have been found in several parts of Syria, but medieval written sources make it clear that paper could be used on arrows to be shot from a hand bow (BAROUDY 2011, p. 204-206). Several surviving arrow shafts from the cave refuge were also decorated in a manner similar to arrows from the Mamluk era displayed in the Museum of Popular Arts and Tradition of Aleppo (BAROUDY 2011, p. 206). These Lebanese fragments also have features in common with fragments from the Citadel of Damascus, especially the varnished binding seen on many otherwise undecorated fragments from CD5 (photograph 3, upper). In addition, one fragment from '⿳亠口冋șî l-Hadat clearly has a red band, an apparently black band, and perhaps even some white (photograph 3, middle). Another fragment from the same location might have the remains of a red band (photograph 3 , lower).

The arrows found in the Citadel of Aleppo probably include examples of both Mamlūk and Ottoman origin. After being kept in the National Museum in Damascus ${ }^{5}$, some (perhaps all) are now back in the Citadel Museum in Aleppo. Even when viewed and photographed from some distance under unfavourable conditions, the similarity between the arrowheads and front shaft bindings of these arrows and some of those found in CD5 is striking. One arrow might have the remains of bands of colour (inv. 1273.6) and another might have a 'patch' decoration similar to arrow fragments from Șadr and Montfort (inv. 5328.4).

The arrow fragments from the castle of Montfort in northern Palestine have been well recorded, preserved, displayed and published by the Israel Antiquities Department. Generally considered to be more likely Mamlük than Crusader, they are thought to be made of cypress wood. Their painted decoration consists of "alternating blue and red bands and 'eye' forms" (BOAS 1999, p. 178) while the 'eye' or 'snake' motifs on the Montfort arrow fragments include two clear examples which are either predominantly green or predominantly red. A third arrow fragment is much more faded. Other fragments from Montfort include one with a complex series of multiple narrow and broad bands which are probably alternating blue and red, as described by Boas, while another is so similar to examples from the Citadel of Damascus that, even in a monochrome photograph, one might assume a red colour around the nock and rear of the shaft.

The finds from the castle of al-Rahba (Qalcat al-Rahba) overlooking the Euphrates valley near Mayādīn in eastern Syria remains problematical. Some are said to now be in the Museum in Dayr al-Zūr while others were said to remain in an archaeological store near al-Rahba itself. However, the astonishing hoard of military equipment which found its way onto the antiquities market in Damascus some decades ago, and which is now largely in the possession of the Qatar Museums Authority, it also thought to come from al-Rahba. In his doctoral thesis, the French archaeologist J. L. Paillet mentioned painted arrows or

5. Where they were given inventory numbers including 0326.4 to 0329.4. 
crossbow bolts from Qalcat al-Rahba when describing the north-western entrance to the castle and the area of severe fire which was found there (PAILLET 1983, p. 20-1; see also p. 42 and plates 17, 18). Although Paillet did not go into further detail concerning the painted cresting, the present author believes that much of this material is now held by the Qatar Museum Authority in Doha, and will hopefully be the subject of a future study.

The military material in Doha, and which is thought to come from al-Rahba, includes material which has been dated by Carbon 14 testing to a period ranging from the late 12 th to late 13th centuries. Unfortunately none of the arrow or crossbow bolt fragments were tested, but a composite bow had a $68 \%$ probability of dating from between 1165 and $1225 \mathrm{AD}$ while a composite crossbow stave a similar probability of date from 1170 to $1250 \mathrm{AD}$. As a result the majority of the military artefacts are though to be from the Ayyūbid and early Mamlūk periods, though perhaps also including material of Turcoman, Mongol or Īl-Khānid origin. The missiles, many of which are virtually complete, overwhelmingly consist of crossbow bolts rather than arrow shafts. Their closest parallels are found amongst the similarly dated but largely unpublished material from Tower 4 of the Citadel of Damascus (see below). Like them, some are decorated or identified with roughly drawn black bands while those from Qalcat al-Rahba are further identified by equally crudely painted and broader bands of red.

Only two Carbon 14 tests have been carried out on the abundant and astonishingly varied military material from Tower 4 of the Citadel of Damascus. These emphatically support an origin in the Mamlük period. It seems, in fact, that most of the finds are early Mamlūk while a few might date from the 14th or 15th centuries. This is further supported by the decoration of some objects and the similaries of others with material from elsewhere in the Citadel of Damascus (namely from CD5). However, most of the missile shafts are again from crossbow bolts rather than arrows for handheld bows. As is normally the case, these crossbow bolts are more crudely made than the arrows. They have paper flights where any flights remain, and quite often also have simple identification marks in the form of black bands around the shafts ahead of the flights (photograph 4). Here it is worth emphasizing the fact that crossbow bolts are distinguished from arrows for handheld bows by their lack of nocks, though in some cases the butts of their shafts are narrowed to fit snugly within the nuts of the crossbow's lock or release mechanism.

Sadly the arrows found in the so-called Tower or Castle of David in Jerusalem during the 19 th century all now seem to have been lost. They were again probably Mamlūk, and were described as being $695 \mathrm{~mm}$ long, with a maximum circumpherance around their shafts of $33 \mathrm{~mm}$, an 'abrupt' end for an arrowhead and a 'bulbous' end for a deep nock (BOAS 1999, p. 191). They were made entirely of wood, with no part being of reed, and were reportedly found in substantial numbers around 1859 in an apparently sealed room which had opened up when some part of the fortified structure collapsed (MERRIL 1906, p. 106). According to Clermont-Ganneau, the example which he himself obtained was 'tapered' at both ends, the rear again being 'bulbous' around the nock. No fletching survived and there was no mention of decoration (CLERMONT-GANNEAU 1901, p. 136-137). 
As already stated, documentary evidence concerning arrows in the medieval Islamic world makes no apparent mention of cresting, decoration or identification on arrows. Nevertheless, some statements could shed an oblique light upon the subject by highlighting the existance of arrows of superior quality or otherwise having 'special' features for use in archery training or competitions. It is, for example, generally agreed by those who have studied furūsiyya literature, that the target arrows used during competions in the maydān (an open area for various forms of military training and parades) were of the highest quality and were sometimes specifically adapted to the archer and his bow. In other words they were personalized (LATHAM \& PATHERSON 1970, p. 26, 28-29; SARRAF 1989, p. 588, 778; CARAYON 2012, p. 358).

How far such personalization was taken is, of course, unclear, and more emphasis was presumably given to the personalization of the bow than to the arrows. Even so it is perhaps worth quoting from a Kipchaq Turkish translation of one of the standard medieval Islamic archery texts, not least because in the context of the 14th century Mamlük Sultanate where it was written, a man who needed to have his text in Turkish was, almost by definition, an active mamlük trooper rather than some civilian seeking to show off his knowledge of archery. This book in Kipchaq Turkish makes it clear that bows varied in length according to the strength of their user and that this effected the arrows to be shot by such bows. Hence;

his arrow(s) will be in accordance with his bow in length. The bow should also be in accordance with the arrow. The length of the arrow is from one tip of the bow to the other, with the exception of the grip.... One should know the length of the arrow first and then obtain a bow according to that [...] The [expert] archers have differed on the qualities of the arrow. Some have said that 'the long arrow is good,' and some have preferred the short arrow." (Anon., Munyatu'l-Ghuzāt 1989, p. 75-76).

One might, therefore, reasonably assume that an archer wanted to be able to easily identify his own 'special' or best missiles. In other words he would have them marked in some way, especially if more than one archer was shooting on the same range, or at the same target during a competition. Furthermore, some forms of archery training such as long distance 'flight' shooting seem to have evolved from an immediate and necessary military skill, as it probably was until the early Mamlūk period, into something more akin to a sport or élite pastime during the late Mamlūk and Ottoman periods (LATHAM 1968, p. 241, 247-248).

More Ottoman arrows survive to be studied, often in excellent condition, than remain from earlier periods. This is often because they were preserved in European museums as battlefield trophies. Others have, course, survived in Turkey itself, as well as in Egypt. In both these parts of what had been the Ottoman Empire, as in many other provinces, flight shooting competitions remained a popular sport well into the 18th century. Nevertheless, Ottoman writen sources, both literary and technical, generally had the same lack of interest in arrows' crestings and other forms of markings. For example, the 15th century Düsturname by Enveri emphasizes the length of Turkish arrows compared to the shorter Crusader arrows which were, in practice, probably crossbow bolts (ENVERI 1954). 
In apparent contradiction, the Burgundian traveller Bertrandon de la Brocquière, who journeyed through both Mamlūk and Ottoman territory in 1432-3, commented on Ottoman archery and stated (Bertrandon de la Brocquière 1988, p. 147-148);

for the Turkish arrows, as we know, are not strong, however strong their bows. Their bows are short and their arrows, too, and light. The iron is set into the wood and would not sustain a heavy blow [...] In case of necessity, our archers could use the Turkish arrows, but they could not use ours because the notches are too narrow and the strings of their bows are too thick since they are made of gut.

Where these arrows were concerned, Bertrandon was probably not comparing Turkish and Mamlūk arrows with European crossbow bolts but with the 'clothyard' arrows shot from so-called longbows of 'self' rather than composite construction which became so famous in English hands during the Hundred Years War.

According to Klopsteg, who based his work on an early 19th century Ottoman Turkish source, there were ten basic types of Ottoman arrow shaft, depending on their shape, fletchings, types of wood and certain other features (KLOPSTEG 1947, p. 75). Some of these differences can be seen in the very varied arrows displayed in the Askerî Müze (Military Museum) in Istanbul. Unfortunately my own photographs of some of these arrows were taken several decades ago, from a distance and only in monochrome. All that can reasonably be said of them is that several arrows clearly have some form of decorative or identifying marks or bands around the rear part of their shafts. However, care must be taken not to confuse such painted bands with the knots on those arrows which were made of reed rather than solid wood.

The 'Islamic-style' arrows which were preserved in good condition in the Sala d'Armi of the Museo dell'Arsenale in Venice, probably included Ottoman and perhaps even late Mamlūk examples along with Venetian 'maritime' or 'colonial' arrows which had much in common with those of their Muslim opponents. The weights of these arrows varied from 50 to 200 grams; the latter probably being massive bolts to be shot from a large crossbow which almost rated as a siege weapon. The lengths of these arrows varied from $640 \mathrm{~mm}$ to $710 \mathrm{~mm}$ (DE LUCIA 1908, p. 83, fig. 72). Their shafts were also painted with one red and two blue bands which, of course, bring to mind those painted arrow nocks from the Citadel of Damascus (CD5) which are the primary focus of the current study.

The 16th century Ottoman arrows in the Museo Nazionale del Bargello in Florence are particularly close to those from CD5. This is apparent in the bindings around the foreparts of their shafts and in some of their blades. Some also have bright decoration or identification marks in black, red, green, white and even gold, as well as other colours which are comparable to those seen in Damascus, plus brass or in one case bone reinforcement rings towards the rear of the shaft (ALEXANDER 2003, p. 134). Their splendour seems likely to indicate associations with soldiers of élite status or perhaps an Ottoman leader since these arrows were probably battlefield trophies rather than having been used for archery training. More, in fact, needs to be known about the history of the Bargello arrows before more emphatic claims are made. 
The reportedly 17th century Ottoman arrows in Poznan are again likely to have been battlefield trophies. They have essentially the same form as well as similar but simpler painted rings around the rear of the shafts (ÇORUHLU 2003, p. 93). These decorative or identification markings are white, black and perhaps red or orange and are remarkably similar to a small number of equally distinctive fragments from CD5.

The Ottoman arrows in the Badischen Landesmuseums, Karlsruhe, are included within a broad selection of largely 17th century battlefield trophies. They are preserved with a quiver, a bow case and a bow; the latter being dated 1678 AD. Even in available monochrome photographs, the arrows appear to have features in common with those in the Bargello and with some from CD5 (PETRASCH 1977, p. 26; PIROVANO 1985, p. 83). Though apparently lacking coloured rings around the rear of the shafts and nocks, the shafts are described as having 'colourful lacquer painting' (PETRASCH 1977, p. 26).

The evidence of archery elsewhere in the later Islamic world indicates a remarkably widespread and to some extent common tradition. For example Faris and Elmer, in appendixes to their translation of Ibn Maymūn's work on archery from 13th century Morocco, described what seemed to be a flightless arrow from Sind in what is now southern Pakistan (FARIS \& ELMER 1945, p. 179);

The nock is bulbous, being almost a sphere nine sixteenths of an inch in diameter, with a slot one quarter of an inch wide and three sixteenths deep. The wood is about as heavy and strong as birch but is concealed by rings of red, yellow, green and black paint. These are modern arrows used by the Sinds of India for the very purpose and in the same way that is ascribed to al-Ṭabari.

The latter was, of course, the 9th century archery expert Abū Muhammad ${ }^{\mathrm{c} A b d}$ al-Raḥmān Aḥmad al-Ṭabarī, not the better known chronicler Abū Ğacfar Muhammad b. Ğarīr al-Ṭabarī who lived from 838 to 923 AD (SARRAF 1996, p. 122).

This brings us to comparative evidence for cresting and other forms of decoration on arrows from medieval cultures which neighboured the Islamic world and may either have influenced Islamic archery traditions or been influenced by them. Once again, some of the best preserved archaeological finds are from the dry or cold regions of Central and Inner Asia. The Turkish Uighurs were culturally close to other Turkish peoples who converted to Islam before the Uighurs themselves did so. This was particularly apparent in their military traditions, including archery. Hence the potential significance of finds of Uighur archery equipment dating from the 9 th to 13 th centuries.

One well preserved archery set was excavated at Balikun (Barhundiy); a second having been excavated at Turfan. According to Y.S. Khudyakov (1998, p. 92-93);

The shafts of all the arrows of both sets have been preserved. These are long cylindrical wooden shafts with arch-shaped nocks for drawing the string [...]. The shaftments of the arrows from Turfan have crests of two varicoloured identifying rings [...] However, since the same rings are painted on the shaftments of the arrows which have different types of piles (arrowheads) and the arrows themselves were put into the quivers the heads upwards, it can be suggested that 
these marks were ${ }^{6}$ made to identify the function of the arrows but they served some other purpose, for example to identify the owner [...] Uigur warriors kept and carried their arrows in open quivers with a pocket. Two such quivers are exhibited in the museums of Hami and Turfan.

In other words in both cases the arrows were put into their quivers with their heads uppermost, so that the nocks could not be seen. This article was accompanied by monochrome drawings which show darker bands around the shafts ahead of, and perhaps beneath the no longer existant flights (KHUDYAKOV 1998, p. 95 fig. 1).

Some Kyrgyz arrows from pre-Islamic 11th-12th century graves in the Upper Yenesi river basin might be similar. However, here the two more obviously differentiated bands around the shafts are closer together, and ahead of where the missing flights were located (KHUDYAKOV 1980, p. 86 fig. 24). Slightly earlier archery equipment from the Turco-Mongol borderlands again shows the difficulty of differentiating between binding which may have been associated with the attachment of the now lost flights, and some form of decoration. For example, on an arrow from an 8th-10th century grave at Üenc Sum, Khovd Aymak in Mongolia, the visible surface feature may in reality have served both functions (URAYKÖHALMi 1968, p. 353 fig. 6/15).

Written sources concerning Mongol archery during the great era of Mongol conquests focussed upon its effectiveness and noted the length of the arrows employed (GAUNT 1973, p. 20; RiCHARD 1979, p. 110), but failed to mention any decorative or identifying features on individual arrows. Nevertheless one may assume that in medieval Mongol society where, with the exception of the finest equipment used by military and political élites, tribal warriors normally made their own equipment (SMiTH 2000, p. 54) - including arrows - such men would have wanted to identify their own missiles.

The medieval Russian arrows displayed in the Historical Museum in Vladimir are presented as if their shafts are original, as are their arrowheads. If this is indeed the case, then the decorative or identification lines around their nocks would have more in common with the arrows of medieval Islamic and Turco-Mongol cultures than those of western Europe. Yet it should also be pointed out that, where arrow shafts are concerned, much less archaeological evidence survives from medieval Europe than it does from Central Asia and the Middle East.

A much later account of how arrows could be decorated was published in Chinese in Taiwan in 1951. This was obtained by C.E. Grayson who had it translated by C.B. Swinford and published in 1981. The result was sent to W.F. Paterson, who then had it republished in a limited edition. William Paterson kindly sent me a copy shortly before his death in 1986. Because this source is so rare, it is worth including a substantial section here. This passage concerns the use of shark skin or snake skin, and ornamental paper as decorative materials.

6. The word 'not' appears be be missing in the published article. 
"1. Glueing the shark skin - cut the shark skin to size and use cow glue to attach it to the nock hat (the bulbous end of the shaft enclosing the nock) and inverted alley (the short length of shaft between the nock 'hat' and the feathers of the flights) for a length of $2.8 \mathrm{~cm}$. If there is no shark skin available, a small snake skin can be substituted. This work is done before attaching the arrowhead.

2. Gluing the ornamental paper - cut the paper into strips of unequal widths. Using different colour strips side by side (for a stripe effect) to wrap the upper portion of the lower foot (the front end of the shaft immediately behind the arrowhead) and the lower portion of the inverted alley (the short length of shaft between the nock 'hat' and the flights) on up. Use cow glue for attaching. This work is done after attaching the shark skin" (T'AN TAN-CHIUNG 1981, p. 207).

\section{Conclusions}

Without clear, contemporary, documentary information about the purpose of markings such as those around the nocks and shafts of arrow fragments from the Citadel of Damascus (CD5), other evidence needs to be studied. Amongst the most illuminating, perhaps, are the contexts and possible purposes of specific training, tactical and organizational systems. Attempting to read more into such colourings and patterns may, nevertheless, be a futile exercise, as noted by V.G. Kishenko (2010, p. 60); "As for the arrow colouring and decoration, they pose a special problem for attributing the specific colouring and decorative features to a particular culture, ethnos tribe or family".

Nevertheless, it is interesting to note that, in the medieval Islamic world, the colour red implied enthusiasm or violence and above all symbolized military courage. Red is, of course, the dominant colour on the arrow fragments. Muslim Arab scholars also reported that, at the battles of Badr (624 AD) and Hunayn (630 AD) at the dawn of Islamic history, the angels who assisted the Muslims against the infidels wore red turbans. Meanwhile blue was seen by medieval Arabs as a 'magical' colour with considerable destructive power and, as such, could have a vital influence on the field of battle. Indeed a projectile that was painted blue might prove particularly deadly (MORABIA 1986, p. 711; ZOUACHE in MOUTON 2010, p. 208).

Pictorial sources are of minimal help in this study because illustrations of arrows in Islamic art, like the art of other cultures, are hardly ever detailed enough to provide information about decorative or other markings. Even when an arrow is itself the subject of an illustration, as in some copies of the Kitāb șuwar al-kawākib by ${ }^{\mathrm{C}} \mathrm{Abd}$ al-Rahmān b. 'Umar al-Ṣuffi, it is only occasionally possible to differentiate between marks which represent binding or strengthening, and those which might represent some form of decoration or identification - or perhaps they were merely the results of an illustrator's imagination. However, the arrow of Sagitarius in a very early 11th century Kitāb șuwar al-kawäkib, probably from Iraq or Iran and now in the Bodleian Library in Oxford, has such a concentration of markings around the shaft beneath the flights that it seems likely that the artist was reflecting a contemporary tradition of marking certain arrows (figure 9). A 
somewhat later copy of the the Kitāb șuwar al-kawākib, probably from Egypt or Iran and dating from $525 \mathrm{AH}(1130 / 1 \mathrm{AD})$ and now in the Topkapi Library, Istanbul, shows an arrow which is in some respects more realistic. It also includes 'incomplete circle' motifs which perhaps bring to mind the 'eye' motifs on a few fragments of arrows from a century or so later (figure 9).

As Simon James pointed out, in the absence of written evidence the purpose of the crestings applied to the arrows from Dura Europos and the surrounding area remain unknown. However, James went on to suggest that they may have been personal designs or may have identified the arrows of a particular military unit. While they may also have been purely decorative, they could even have had some magical significance, particularly as James thinks that the markings on two arrows (nos. 734 and 735) ${ }^{7}$ (figures 8/3-4) might represent eyes (JAMES 2004, p. 1969). If this interpretation is corrent, then it surely brings to mind the supposed 'eye' motifs on some arrow fragments from Șadr and Montfort, while the painting around and, in the case of 735 and 736 even within the nock, similarly bring to mind other painted fragments from CD5. Taken together, these elements of cresting are further evidence of a remarkable degree of military-technological continuity which characterized the Roman, Byzantine and medieval Islamic Middle East. Such continuity can also be seen in several other aspects of weaponry and armour, not to mention certain aspects of military organization and tactics.

The lack of mention of colouring on arrows in Arab, Persian or Turkish medieval epic literature and verse suggests that it was not regarded as significant, being merely a minor technical aspect of archery and its training. But even if such literary texts appear to make no specific mention of arrows with cresting, a variety of sources both literary and technical shed light on the context in which arrows were used. From these one may deduce a number of logical reasons why arrows should be given highly distinctive coloured markings.

Firstly, the astonishing degree of continuity in training methods and tactical practice amongst the fursān or professional cavalry élite during the medieval Islamic centuries needs to be emphasized once again. It is not only seen in the continued use and frequent updating of furūsìya texts - itself still a somewhat contentious subject - but in the striking similarities which can be seen in texts whose dates of origin are not disputed. For example, the treatise on archery written by Ṭaybugiā al-Ašrafī al-Baklamīš̄ al-Yunānī around 1368 AD in Mamlük Syria, is thought to be the first such work to focus upon archery from horseback. Nevertheless the author stated that his work was based on the traditions of both the 'Turks', by whom he meant the nomadic Turks and perhaps also the Mongols, and on the traditions of the fursān, by whom he meant the long-established professional Islamic cavalry élite. The latter were, by Ṭaybug̈à's day, largely of mamlūk, that is supposedly slave-recruited, origin, though this was never entirely the case across those countries which had, and still did, rely upon the military traditions of the fursān. Obviously Țaybugià

7. These numbers are those given by S. James in his study, and are not the Yale University Art Gallery inventory numbers. 
regarded the fursān and Turkish traditions as distinct from one another, though equally obviously they also had features in common. Hence it is interesting to note that, according to Țaybuga à, the final action of a horse archer during a training exercise in which he shot his arrow or arrows at the gallop (sawq), was gaawalān or 'wheeling aside' (LATHAM 1969, p. 258). The same action was implied by al-Ğāhiz in his comparison of the archery tactics of the 9th century Hurāsānī troops (Arabs long settled in eastern Iran) and the 'Turks' in the 'Abbāsid armies of his day. These Hurāsānī were fully armoured cavalry who "discharge far arrows of the nim (or nayam) tree", and who trained for war using the dabbūq game and practiced archery against the birğās target (al-Ǧăhiz, tr. 1915, p. 646; Rasä̉il, p. 19-20). Furthermore, unlike the 'Turks', "they (the Hurāsānī) wheel aside" which sounds very much like the ğawalān manoeuvre described five centuries later by Ṭaybuğà (al-Ǧāhị, tr. 1915, p. 666; Rasā̉il, p. 45-46).

In 13th century Islamic northern India, Muhammad b. Manșūr Faḩr al-Dīn Mubārakšāh was especially concerned with the sorts of feather to be used for an arrow's flights, and to a lesser extent with the shafts, but he made no mention of cresting or any other form of decoration (Mubārakšāh 1974, p. 94-95). Writing at a similar date far away in the westernmost regions of the medieval Islamic world in Morocco, Ibn Maymūn described archery competions and even explained some of the cheating which could take place. One such trick could happen when two archers used the same arrow, and seems to indicate that this was common practice if competitors agreed to it (FARIS \& ELMER 1945, p. 121-122). Apparently both archers also used the same bow, presumably to remove an advantage possessed by an archer with a better bow or arrow. Perhaps it also implied that at least the arrow or arrows could be easily recognized.

During the following century, on the other side of the Straits of Gibraltar in the Emirate of Granada, 'A Alī b. 'Abd al-Raḥmān Ibn Hudayl al-Andalusī, wrote enthusiastically about the joys of target shooting (Ibn Hudayl, tr. 1924 p. 251-255; tr. 1977, p. 206-7). He described how the archer loosed a sequence of arrows; usually six, each of which had a name. Each subsequent shot ought to be more accurate than its predecessor in a method of shooting which was remarkably like the ranging and 'bracketing' used by 20th century artillery. There was an expectation that the sixth arrow should hit the mark. Presumably the same should also be true of the fifth arrow as Ibn Hudayl maintained that getting two out of six on the target was 'ordinary', while anything above that showed real expertise. Unfortunately the further details provided by Ibn Hudayl focused upon the types of arrowheads, not the arrow shafts, nor their fletching, nocks or cresting.

Not surprisingly, there is more of what might called contextual written evidence from the Mamlūk period. We know, for example, that Sultan al-Nașīr had archery practice ranges belonging to the amirs (senior officers) closed down in $733 \mathrm{AH}$ (1332-3 AD), leaving only those belonging to the sultan himself (LATHAM \& PATERSON 1970, p. xxiv). Might a resulting concentration of training on 'official' ranges have increased the need for a specific identification of arrows and their owners? According to Muhammad Ibn Iyās, in 1513 AD within a few years of the fall of the Mamlūk Sultanate, the Sultan gave his own hășșakiyya 
closest guard unit equipment which had belonged to mamlūk soldiers who died of plague. This included quivers and arrows, seeming to indicate that such arrows had been the specific and identifiable property of the deceased troopers (Ibn Iyās 1931, p. 359-360). Two years later, as the final crisis approached, the Sultan again gave quivers, bows and arrows to élite troops, seemingly from an arsenal which formed a reserve of equipment which had previously belonged to Mamlūks who died of plague and which had been retained for just such an emergency (Ibn Iyās, tr. 1955, p. 335).

Over a century earlier the Mamlūk scholar and retired officer, Muhammad Ibn Manglī (al-Manqalī) al-Nāșirī, went into huge detail about the bow and its proper use in his work on hunting (Ibn Manglī 1984, p. 61-65), but makes no reference to identification or other marks on the arrows. Instead he merely warns that the correct arrow must be used for whatever strength of bow has been selected. Perhaps hunting was not an activity in which one would expect to use one's best arrows, since there was a high probability of them being broken or lost. Similarly, S. al-Sarraf's thesis on mamlūk archery makes no mention of colouring or anything that might relate to colouring on arrows (SARRAF 1989).

An Ottoman source which highlights the priorities at work during traditional archery competions was interpretted by Paul Klopsteg as follows. Thirty practice arrows were called a 'bundle' and they must all be alike, so that the learner can judge whether he is doing everything correctly. If the arrows were unlike, the learner could not tell whether any fault lay in himself or in the arrows (KLOPSTEG 1947, p. 77). Klopsteg then described archery practice in an open space called the Ok Maidan where a student or a person practicing archery shot 60 to 100 arrows a day (KLOPSTEG 1947, p. 114). There were likely to be a number of men practising at the same time and in the same place; hence there would clearly be a great need to identify individual arrows. An officially recognized Tournament Season was also held on the Ok Meidan of Istanbul, carried out under strict rules concerning who would shoot, how many arrows could be used, and so on. The Tournament Season began during the spring festival and ended on 8th November each year (KLOPSTEG 1947, p. 115), during which the entire process was clearly highly formal. During this Tournament Season, on Mondays and Thursdays, there would be numerous archers taking part in competition in one relatively confined area. However there was no shooting on Sundays and Wednesdays, though it remained normal on the three remaining days of the week. 


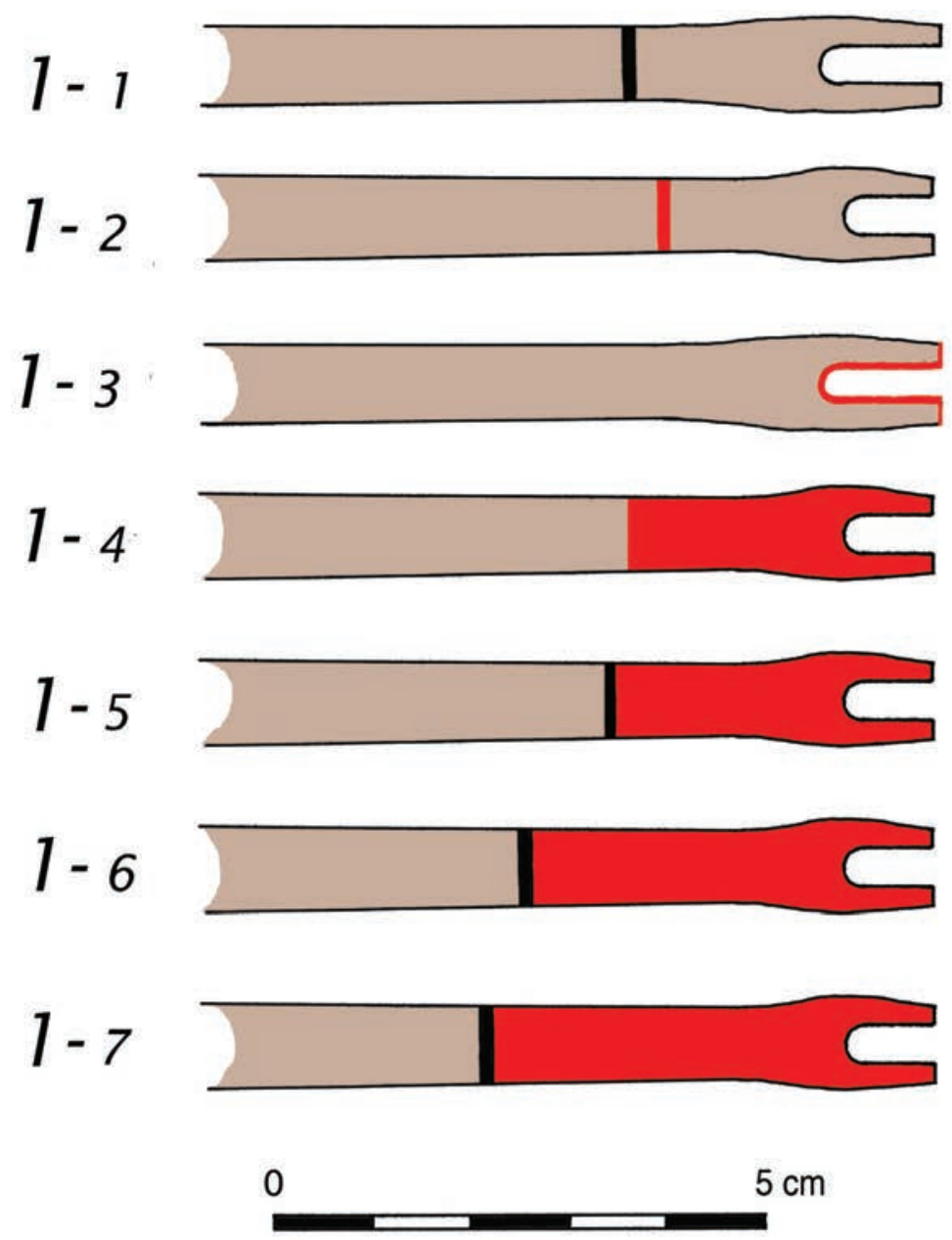

\begin{tabular}{|c|c|c|c|c|}
\hline Number & Type & Shape & Inventory numbers & Comments \\
\hline $1-1$ & $1 / \mathrm{a} / 2$ & A2 & CD $5.2412(x 4)$ & Distance of black line from butt from 29 to $32 \mathrm{~mm}$ \\
\hline $1-2$ & $1 / \mathrm{a} / 3$ & A1 & CD $5.2412(x 2)$ & Distance of red line from butt from 26 to $29 \mathrm{~mm}$ \\
\hline $1-3$ & $1 / \mathrm{a} / 4$ & A2 & CD $5.2412(x 1)$ & Red on butt $\&$ inside nock \\
\hline $1-4$ & $1 / \mathrm{b} / 1$ & A1 & CD $5.2412(x 5)$ & Length of red band from 25 to $30 \mathrm{~mm}$ \\
\hline $1-5$ & $1 / \mathrm{b} / 2$ & A1 & $\begin{array}{l}\text { CD } 2.5300(\mathrm{x} 2) \\
\text { CD } 2.5411(\mathrm{x} 1) \\
\text { CD } 2.5412(\mathrm{x} 8)\end{array}$ & $\begin{array}{l}\text { Length of red band from } 25 \text { to } 32 \mathrm{~mm} \\
\text { Length of red band from } 25 \text { to } 32 \mathrm{~mm} \\
\text { Length of red band from } 25 \text { to } 32 \mathrm{~mm}\end{array}$ \\
\hline $1-6$ & $1 / \mathrm{b} / 2$ & A1 & $\begin{array}{l}\text { CD } 2.5300(x 1) \\
\text { CD } 2.5412(x 7)\end{array}$ & $\begin{array}{l}\text { Length of red band from } 33 \text { to } 37 \mathrm{~mm} \\
\text { Length of red band from } 33 \text { to } 37 \mathrm{~mm}\end{array}$ \\
\hline $1-7$ & $1 / \mathrm{b} / 2$ & A1 & CD $2.5412(x 2)$ & Length of red band from 38 to $45 \mathrm{~mm}$ \\
\hline
\end{tabular}

Figure 1 

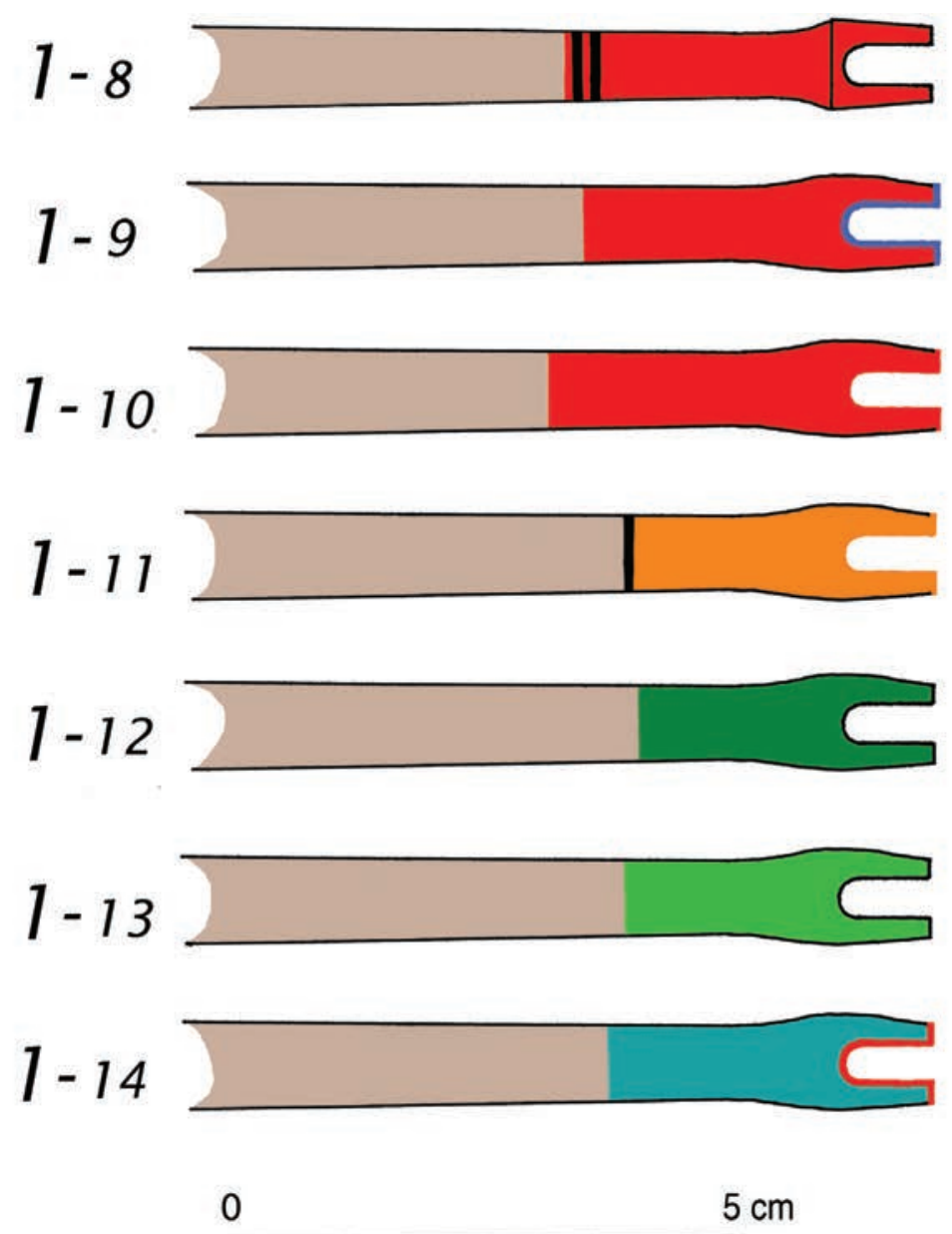

\begin{tabular}{|c|c|c|c|c|}
\hline Number & Type & Shape & Inventory numbers & Comments \\
\hline $1-8$ & $1 / \mathrm{b} / 3$ & $\mathrm{C}$ & CD $5.2411(x 1)$ & Length of red band including black lines $35 \mathrm{~mm}$ \\
\hline $1-9$ & $1 / \mathrm{b} / 4$ & A1 & $\begin{array}{l}\text { CD } 5.2408(x 1) \\
\text { CD } 5.2412(x 2)\end{array}$ & $\begin{array}{l}\text { Length of red band } 34 \mathrm{~mm} \text {, also blue on butt \& inside nock } \\
\text { Length of red band } 32 \mathrm{~mm} \text {, also blue on butt \& inside nock }\end{array}$ \\
\hline $1-10$ & $1 / \mathrm{b} / 5$ & A1 & $\begin{array}{l}\text { CD } 5.2412(x 2) \\
\text { CD } 5.2421(x 1)\end{array}$ & $\begin{array}{l}\text { Length of red band from } 28 \text { to } 36 \mathrm{~mm} \text {, also red on butt \& inside nock } \\
\text { Length of red band from } 38 \mathrm{~mm} \text {, also red on butt \& inside nock }\end{array}$ \\
\hline $1-11$ & $1 / \mathrm{c} / 1$ & A1 & CD $5.2414(x 1)$ & Length of orange band $30 \mathrm{~mm}$, also orange on butt $\&$ inside nock \\
\hline $1-12$ & $1 / \mathrm{d} / 1$ & A1 & CD $5.2401(x 1)$ & Length of dark green band $30 \mathrm{~mm}$ \\
\hline $1-13$ & $1 / \mathrm{d} / 2$ & A1 & CD $5.2412(x 1)$ & Length of mid-green band $31 \mathrm{~mm}$ \\
\hline $1-14$ & $1 / \mathrm{e} / 1$ & A1 & $\begin{array}{l}\text { CD } 5.2408(x 1) \\
\text { CD } 5.2414(x 1)\end{array}$ & $\begin{array}{l}\text { Length of blue-green band } 32 \mathrm{~mm} \text {, also red on butt \& inside nock } \\
\text { Length of blue-green band } 32 \mathrm{~mm} \text {, also red on butt \& inside nock }\end{array}$ \\
\hline
\end{tabular}

Figure 2 

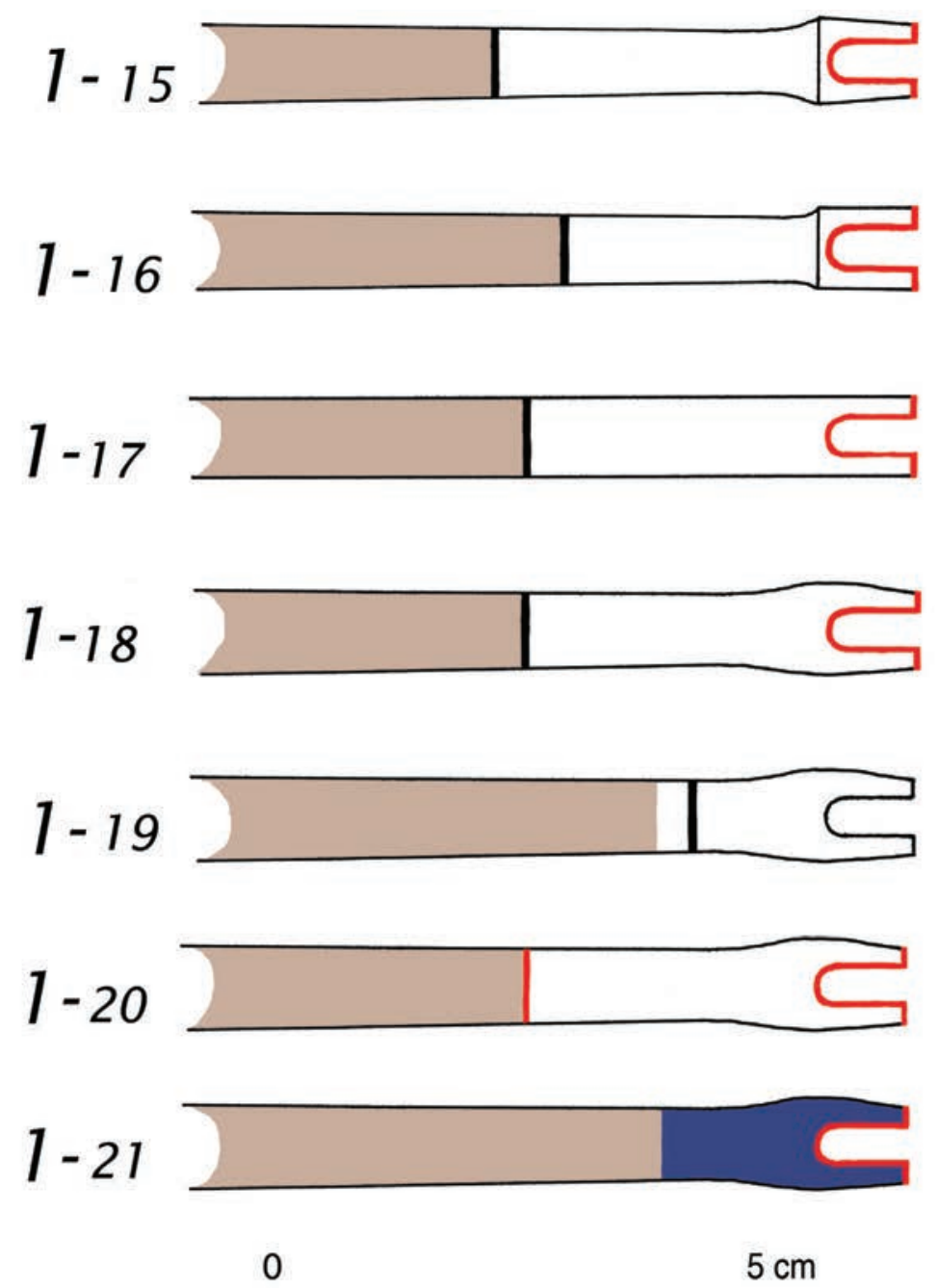

\begin{tabular}{|c|c|c|c|c|}
\hline Number & Type & Shape & Inventory numbers & Comments \\
\hline $1-15$ & $1 / \mathrm{f} / 1$ & $\mathrm{C}$ & $\begin{array}{l}\text { CD } 5.2401(x 1) \\
\text { CD } 5.2408(x 1)\end{array}$ & $\begin{array}{l}\text { Length of white band } 42 \mathrm{~mm} \text {, also red on butt } \& \text { inside nock } \\
\text { Length of white band } 40 \mathrm{~mm} \text {, also red on butt \& inside nock }\end{array}$ \\
\hline $1-16$ & $1 / f / 1$ & B & CD $5.2413(x 1)$ & Length of white band $30 \mathrm{~mm}$, also red on butt \& inside nock \\
\hline $1-17$ & $1 / \mathrm{f} / 1$ & $\mathrm{D}$ & CD $5.2414(x 1)$ & Length of white band $32 \mathrm{~mm}$, also red on butt $\&$ inside nock \\
\hline $1-18$ & $1 / \mathrm{f} / 1$ & A1 & CD $5.2412(\mathrm{x} 2)$ & Length of white band $32 \mathrm{~mm}$, also red on butt \& inside nock \\
\hline $1-19$ & $1 / \mathrm{f} / 2$ & A1 & CD $5.2405(x 1)$ & Length of white band including black line $23 \mathrm{~mm}$ \\
\hline $1-20$ & $1 / \mathrm{f} / 3$ & A1 & CD $5.2414(x 1)$ & $\begin{array}{l}\text { Length of white band plus red line } 39 \mathrm{~mm} \text {, also red on butt \& inside } \\
\text { nock }\end{array}$ \\
\hline $1-21$ & $1 / \mathrm{g} / 1$ & A1 & CD $5.2414(x 1)$ & Length of blue-black band $25 \mathrm{~mm}$, also red on butt \& inside nock \\
\hline
\end{tabular}

Figure 3 


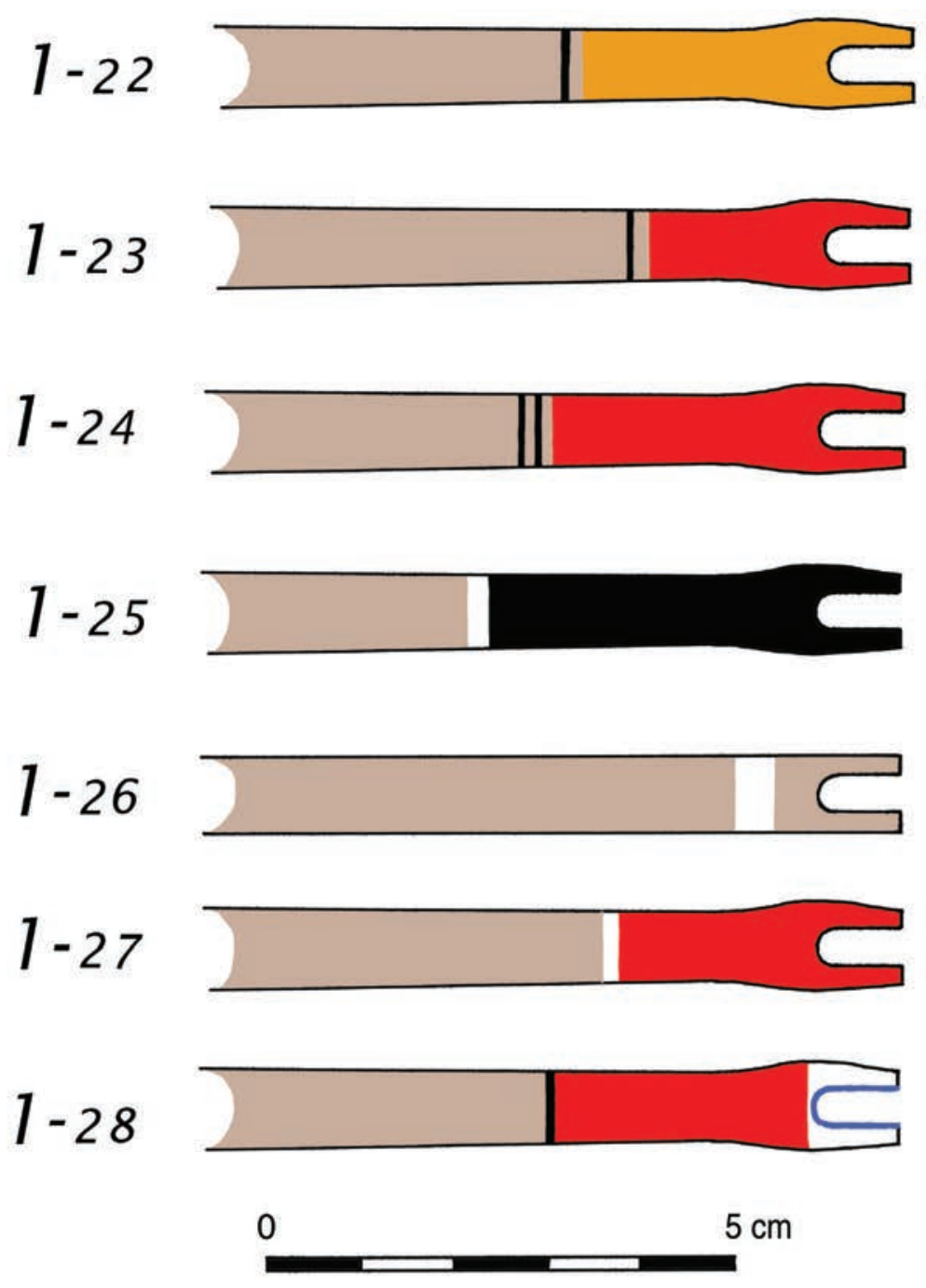

\begin{tabular}{|c|c|c|c|c|}
\hline Number & Type & Shape & Inventory numbers & Comments \\
\hline $1-22$ & $2 / \mathrm{a} / 1$ & A1 & CD $5.2412(x 1)$ & $\begin{array}{l}\text { Length of orange band } 34 \mathrm{~mm} \text {; black line } 3 \mathrm{~mm} \text { forward of orange } \\
\text { band }\end{array}$ \\
\hline $1-23$ & $2 / \mathrm{b} / 1$ & A1 & CD $5.2412(x 10)$ & $\begin{array}{l}\text { Length of red band from } 25 \text { to } 38 \mathrm{~mm} \text {; black line } 3 \mathrm{~mm} \text { forward of red } \\
\text { band }\end{array}$ \\
\hline $1-24$ & $2 / \mathrm{b} / 2$ & A1 & CD $5.2412(x 2)$ & $\begin{array}{l}\text { Length of red band } 34 \mathrm{~mm} \text {; two black lines } 2 \& 4 \mathrm{~mm} \text { forward of red } \\
\text { band }\end{array}$ \\
\hline $1-25$ & $2 / \mathrm{c} / 1$ & A1 & CD $5.2412(x 1)$ & Length of black band $45 \mathrm{~mm}$; black line $3 \mathrm{~mm}$ forward of black band \\
\hline $1-26$ & $2 / \mathrm{d} / 1$ & $\mathrm{D}$ & CD $5.2421(x 1)$ & Width of white band $4 \mathrm{~mm}$, set $9 \mathrm{~mm}$ ahead of butt \\
\hline $1-27$ & $2 / \mathrm{e} / 1$ & A1 & $\begin{array}{l}\text { CD } 5.2412(x 1) \\
\text { CD } 5.2413(x 1)\end{array}$ & $\begin{array}{l}\text { Length of red band } 42 \mathrm{~mm} \text {, length of white band } 2 \mathrm{~mm} \\
\text { Length of red band } 42 \mathrm{~mm} \text {, length of white band } 2 \mathrm{~mm}\end{array}$ \\
\hline $1-28$ & $2 / \mathrm{e} / 2$ & A1 & CD $5.2414(x 1)$ & $\begin{array}{l}\text { Length of white band } 8 \mathrm{~mm} \text {, length of red band } 30 \mathrm{~mm} \text {, also blue on } \\
\text { butt \& inside nock }\end{array}$ \\
\hline
\end{tabular}

Figure 4 


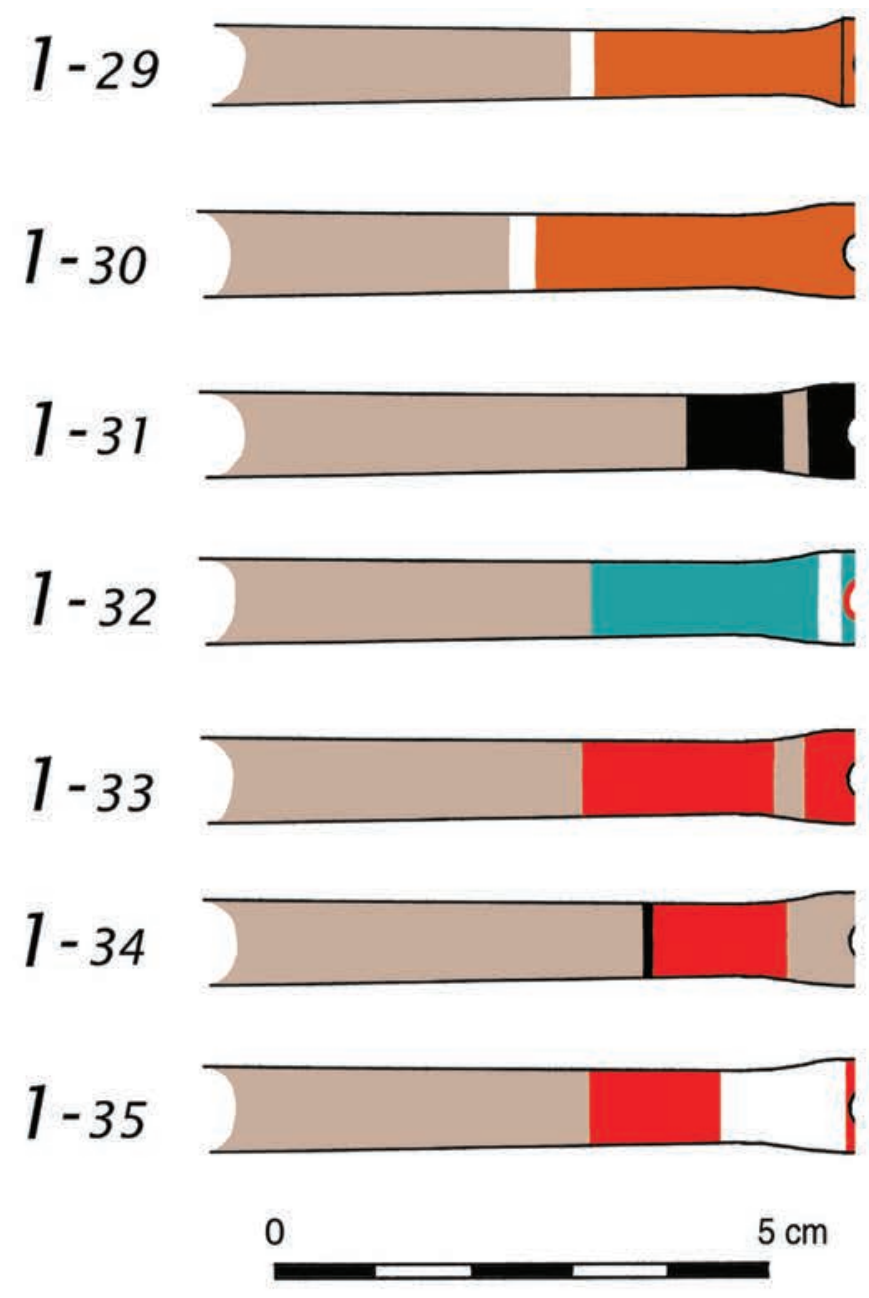

\begin{tabular}{|c|c|c|c|c|}
\hline Number & Type & Shape & Inventory numbers & Comments \\
\hline $1-29$ & $2 / \mathrm{f} / 1$ & $\mathrm{C}$ & CD $5.2411(x 1)$ & Length of brown band $34 \mathrm{~mm}$, length of white band $3 \mathrm{~mm}$ \\
\hline $1-30$ & $2 / \mathrm{f} / 1$ & A1 & CD $5.2412(x 2)$ & Length of brown band $37 \mathrm{~mm}$, length of white band $3 \mathrm{~mm}$ \\
\hline $1-31$ & $3 / a / 1$ & A1 & CD $5.2412(x 5)$ & $\begin{array}{l}\text { Length of two black band including band of bare wood from } 25 \text { to } \\
30 \mathrm{~mm}\end{array}$ \\
\hline $1-32$ & $3 / \mathrm{b} / 1$ & A1 & CD $5.2408(x 1)$ & $\begin{array}{l}\text { Length of blue-green around nock } 8 \mathrm{~mm} \text {, length of white band } 4 \mathrm{~mm} \text {, } \\
\text { length of blue-green band at rear of shaft } 23 \mathrm{~mm} \text {, also red on butt } \\
\& \text { inside nock }\end{array}$ \\
\hline $1-33$ & $3 / \mathrm{c} / 1$ & A1 & CD $5.2421(x 1)$ & Length of red band $34 \mathrm{~mm}$, including $3 \mathrm{~mm}$ wide band of bare wood \\
\hline $1-34$ & $3 / \mathrm{c} / 2$ & A1 & CD $5.2413(x 1)$ & Length of red band $27 \mathrm{~mm}$, including $9 \mathrm{~mm}$ wide band of bare wood \\
\hline $1-35$ & $3 / \mathrm{d} / 1$ & A1 & $\begin{array}{l}\text { CD } 5.2300(x 1) \\
\text { CD } 5.2335(x 1) \\
\text { CD } 5.2408(x 4) \\
\text { CD } 5.2410(x 2) \\
\text { CD } 5.2413(x 1) \\
\text { CD } 5.2421(x 3)\end{array}$ & $\begin{array}{l}\text { Combined length of red \& white bands } 30 \mathrm{~mm} \text {; length of white band } \\
12 \mathrm{~mm} \\
\text { Total length of red \& white bands } 34 \mathrm{~mm} \text {; length of white band } \\
10 \mathrm{~mm} \\
\text { Total length of red \& white bands } 30 \text { to } 35 \mathrm{~mm} \text {; length of white band } \\
\text { from } 4 \text { to } 8 \mathrm{~mm} \\
\text { Total length of red \& white bands } 30 \mathrm{~mm} \text {; length of white band } 7 \mathrm{~mm} \\
\text { Total length of red \& white bands } 24 \mathrm{~mm} \text {; length of white band } 6 \mathrm{~mm} \\
\text { Total length of red \& white bands } 28 \mathrm{~mm} \text {; length of white band } 4 \mathrm{~mm}\end{array}$ \\
\hline
\end{tabular}




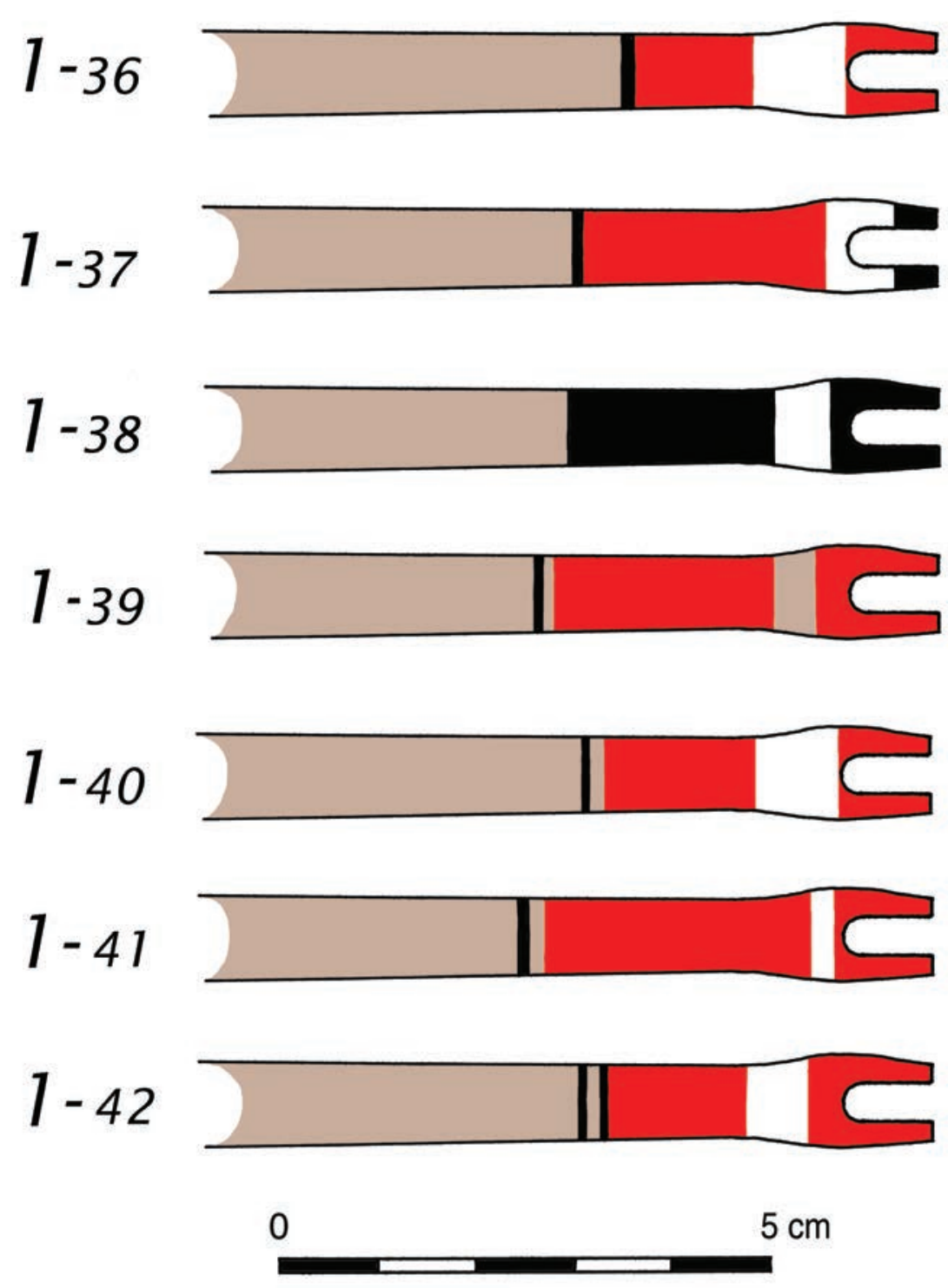

Figure 6 


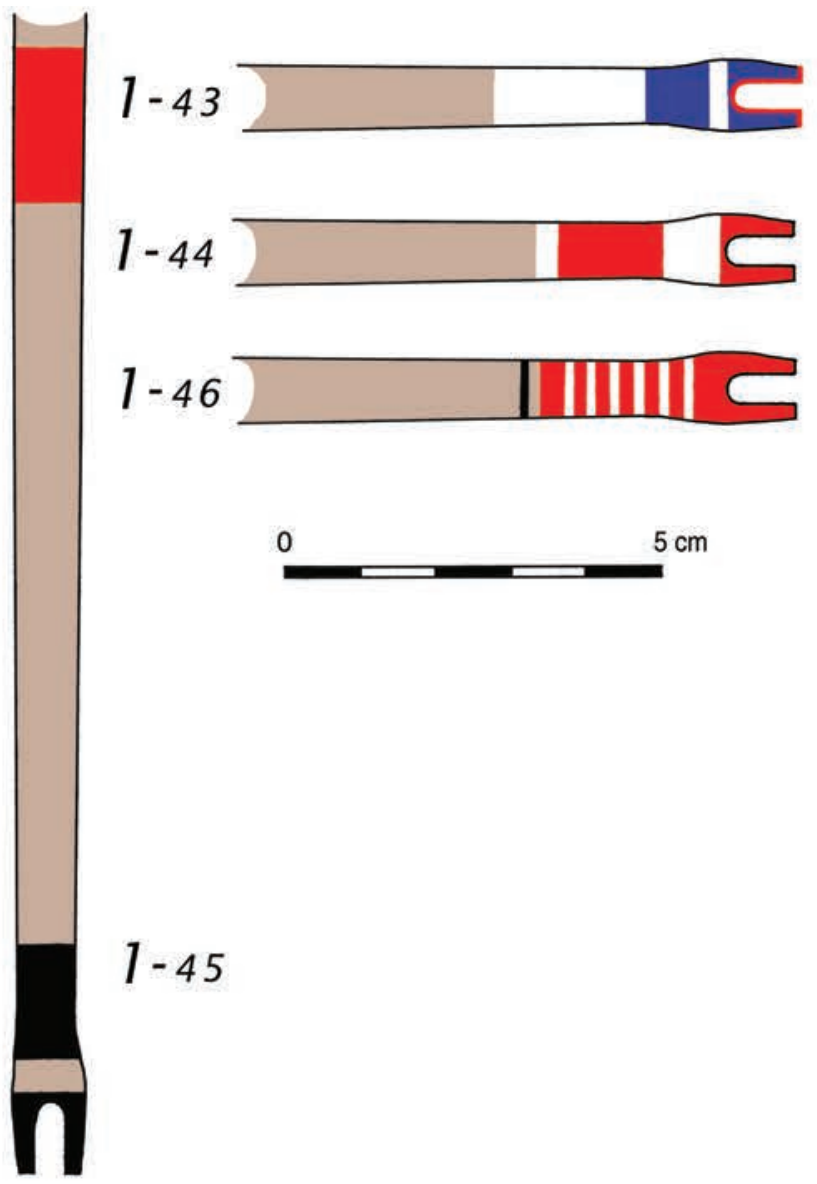

\begin{tabular}{|c|c|c|c|c|}
\hline Number & Type & Shape & Inventory numbers & Comments \\
\hline $1-43$ & $4 / c / 1$ & Al & CD $5.2414(\mathrm{xl})$ & $\begin{array}{l}\text { Length of white band around rear of shaft } 20 \mathrm{~mm} \text {; length of blue-black } \\
\text { band } 25 \mathrm{~mm} \text { including } 3 \mathrm{~mm} \text { wide band ahead of nock, also red on butt } \\
\& \text { inside nock }\end{array}$ \\
\hline $1-44$ & $4 / \mathrm{d} / 1$ & A1 & CD $5.2413(x 1)$ & $\begin{array}{l}\text { Length of white band around rear of shaft } 3 \mathrm{~mm} \text {, length of red band } \\
\text { around rear of shaft } 13 \mathrm{~mm} \text {, length of white band ahead of nock } 7 \mathrm{~mm} \text {, } \\
\text { length of red band around nock } 10 \mathrm{~mm}\end{array}$ \\
\hline $1-45$ & $5 / \mathrm{a} / 1$ & Al & CD $5.2401(\mathrm{x} 2)$ & $\begin{array}{l}\text { Length of red band around rear half of shaft } 20 \mathrm{~mm} \text {, length of bare } \\
\text { wood around rear half of shaft between red \& black bands } 98 \mathrm{~mm} \text {, } \\
\text { length of black band ahead of nock } 16 \mathrm{~mm} \text {, length of bare wood around } \\
\text { front of nock } 4 \mathrm{~mm} \text {, length of black band around nock } 10 \mathrm{~mm}\end{array}$ \\
\hline $1-46$ & $6 / a / 1$ & A1 & CD $5.2412(x 1)$ & $\begin{array}{l}\text { Length of red bands including six } 2 \mathrm{~mm} \text { wide narrow white bands } 34 \mathrm{~mm} \text {; } \\
\text { note } 2 \mathrm{~mm} \text { wide band of bare wood between red bands \& black line }\end{array}$ \\
\hline $1-43$ & $4 / d / 1$ & A1 & CD $5.2414(\mathrm{x} 1)$ & $\begin{array}{l}\text { Length of white band around rear of shaft } 20 \mathrm{~mm} \text {; length of blue-black } \\
\text { band } 25 \mathrm{~mm} \text { including } 3 \mathrm{~mm} \text { wide band ahead of nock, also red on butt } \\
\& \text { inside nock }\end{array}$ \\
\hline $1-44$ & $4 / d / 1$ & A1 & CD $5.2413(x 1)$ & $\begin{array}{l}\text { Length of white band around rear of shaft } 3 \mathrm{~mm} \text {, length of red band } \\
\text { around rear of shaft } 13 \mathrm{~mm} \text {, length of white band ahead of nock } 7 \mathrm{~mm} \text {, } \\
\text { length of red band around nock } 10 \mathrm{~mm}\end{array}$ \\
\hline $1-45$ & $5 / a / 1$ & A1 & CD $5.2401(x 2)$ & $\begin{array}{l}\text { Length of red band around rear half of shaft } 20 \mathrm{~mm} \text {, length of bare } \\
\text { wood around rear half of shaft between red \& black bands } 98 \mathrm{~mm} \text {, } \\
\text { length of black band ahead of nock } 16 \mathrm{~mm} \text {, length of bare wood around } \\
\text { front of nock } 4 \mathrm{~mm} \text {, length of black band around nock } 10 \mathrm{~mm}\end{array}$ \\
\hline $1-46$ & $6 / a / 1$ & A1 & CD $5.2412(x 1)$ & $\begin{array}{l}\text { Length of red bands including six } 2 \mathrm{~mm} \text { wide narrow white bands } 34 \mathrm{~mm} \text {; } \\
\text { note } 2 \mathrm{~mm} \text { wide band of bare wood between red bands \& black line }\end{array}$ \\
\hline
\end{tabular}



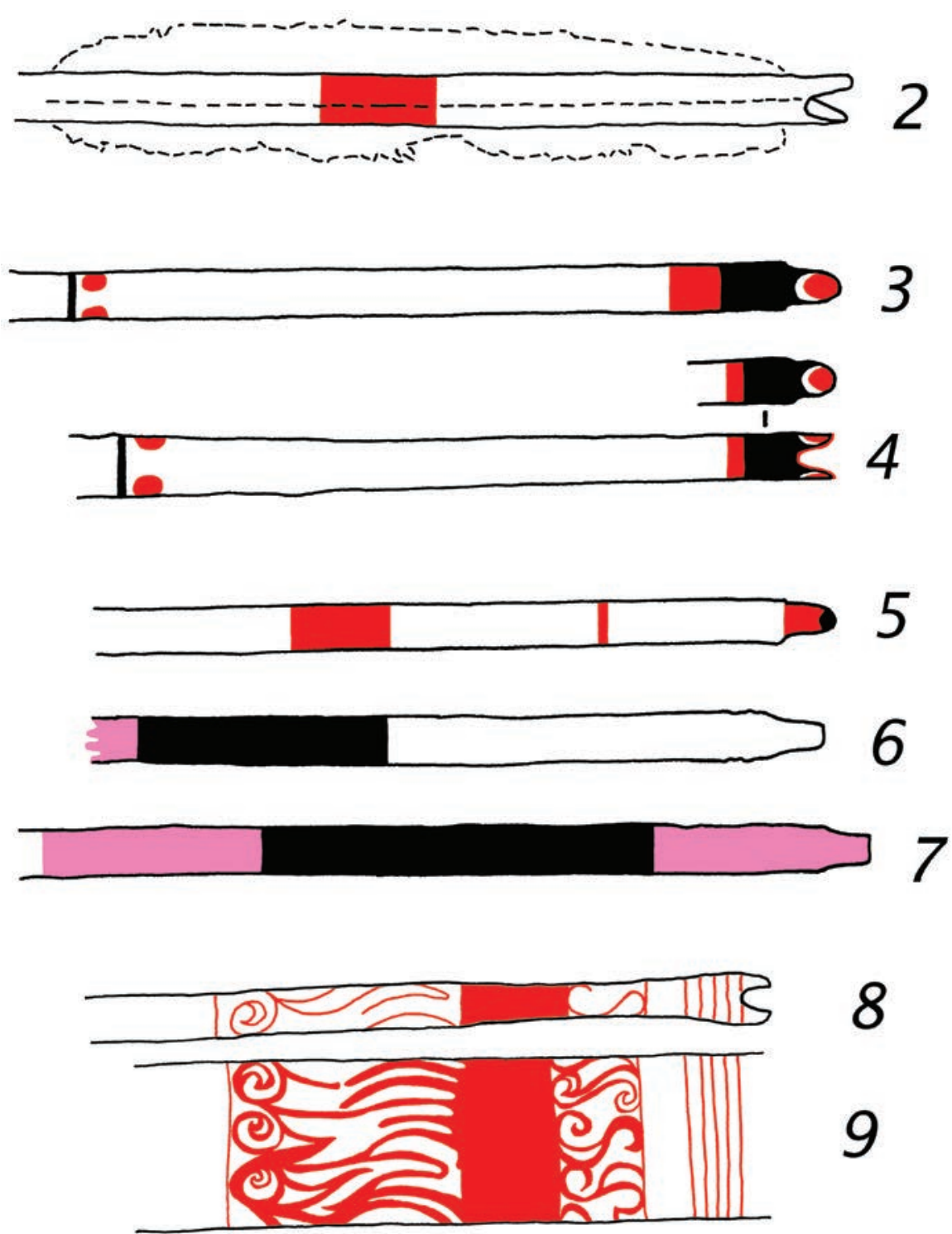

Figure 8

Drawings 2, 3, 4, 5, 6, 7: Schematic representation of cresting on an arrow fragment from Dura Europos, Syro-Roman mid-3rd cent. AD (Yale University Art Gallery, inv. 1933.445a, b, c; 1938.5999 .1070 and 1069; 1932.1685; after JAMES 2004, p. 208 \& fig. 124 (733- 738)).

Drawing 8: One of the arrows found in a leather quiver, from Grave no. 5, Saryg-Bulan at Bayan-Kol, Tuva Autonomous Region, possibly eastern Scythian, 5th cent. BC (after SEMENOV \& KILUNOVSKAYA 1990, p. 44-56 \& fig. 4).

Drawing 9: Decoration 'unrolled' from one of the arrows found in a leather quiver, from Grave no. 5, Saryg-Bulan at Bayan-Kol, Tuva Autonomous Region, possibly eastern Scythian, 5th cent. BC (after SEMENOV \& KILUNOVSKAYA 1990, p. 44-56, fig. 4). 


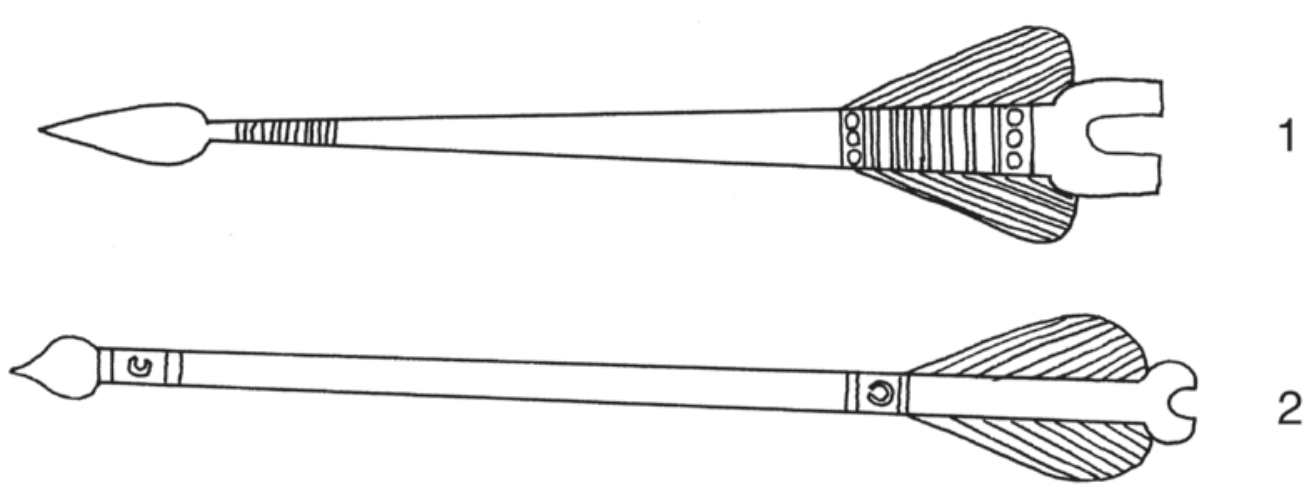

Figure 9

Drawing 1: "Arrow of Sagitarius", Kitāb Șuwar al-Kawākib by cAbd al-Raḥmān b. 'Umar al-Ṣūfī, probably Iraq or Iran, 1009 AD (Bodleian Library, Ms. Marsh 144, f. 140, Oxford).

Drawing 2: "Arrow of Sagitarius", Kitāb Șuwar al-Kawākib by cAbd al-Raḥmān b. cUmar al-Ṣūfī, probably Egypt or Iran, 1130/1 AD (Topkapi Library, Ms. Ahmad III 3493, f. 40v, Istanbul). 


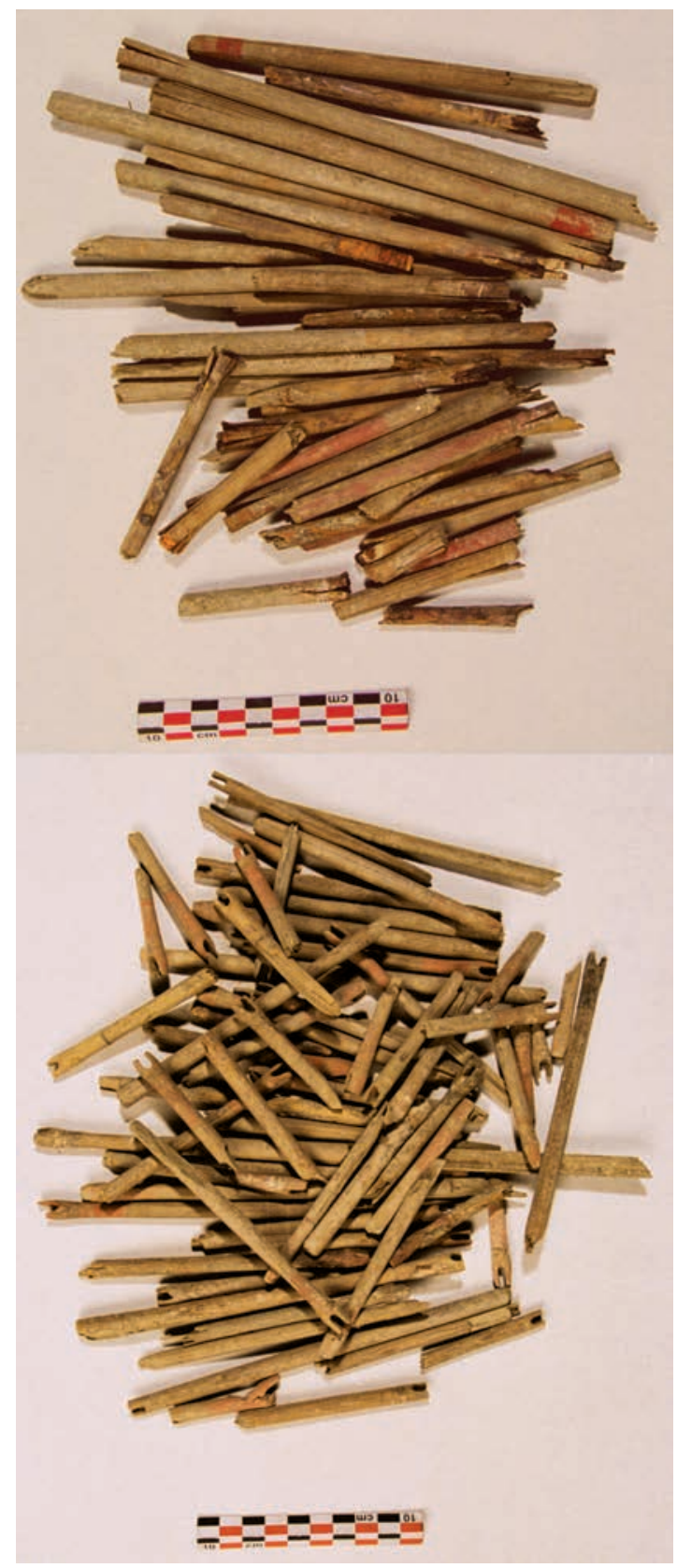

Photograph 1: Arrows from the Citadel of Damascus (chamber CD5), Mamlük late 15th-early 16th cents., or Ottoman 16th century AD (Ministry of Antiquities, Damascus; Ifpo P. Godeau photographs). 

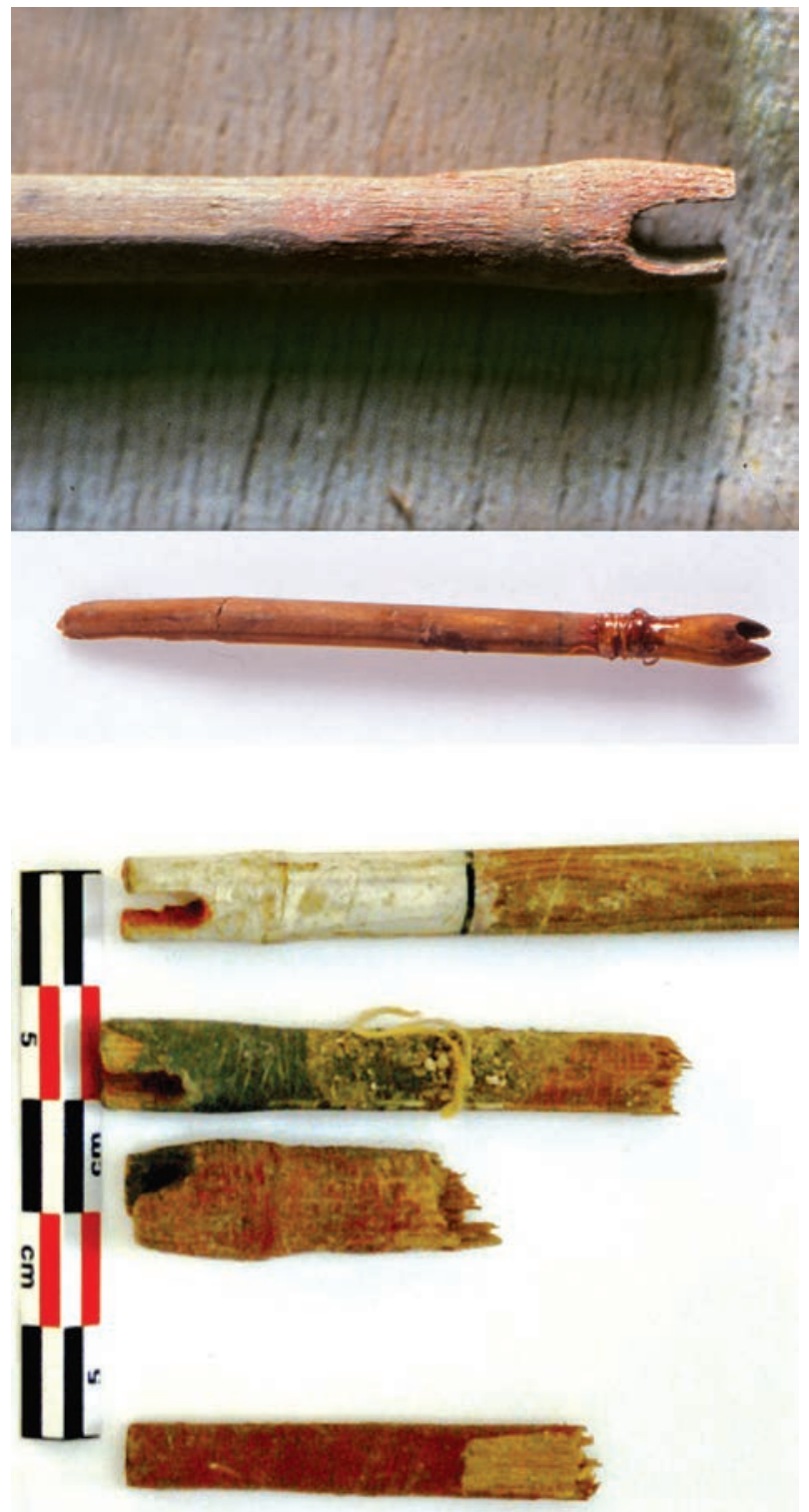

Photograph 2: Arrows from the Citadel of Damascus (chamber CD5), Mamlūk late 15th-early 16thcents., or Ottoman 16th century $A D$ (Ministry of Antiquities, Damascus; Ifpo P. Godeau photographs). 

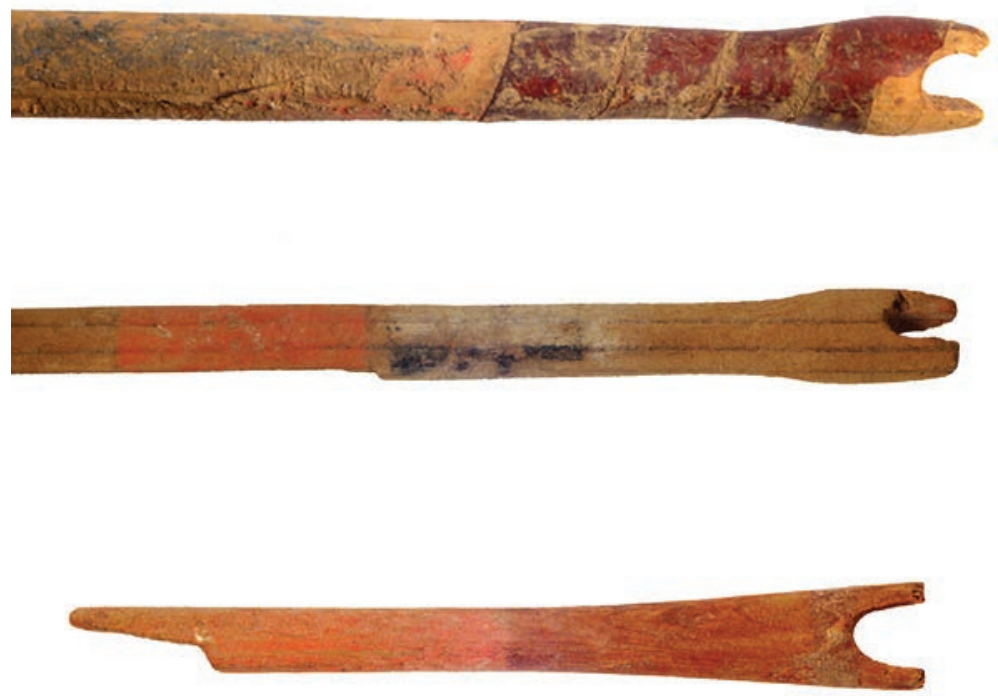

Photograph 3: Arrows from the cave-refuge of ${ }^{c} \bar{A} s \underline{\imath} l$ l-Hadaț, Lebanon, Maronite and/or Mamlūk, c.1283 AD (Fadi Baroudy photographs).

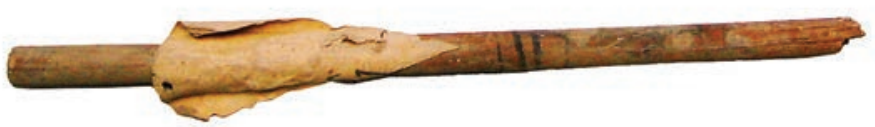

Photograph 4: Crossbow bolt from the Citadel of Damascus (chamber T4), Mamlūk mid-13th-14th cents. AD (Ministry of Antiquities, Damascus; author's photograph). 


\section{Bibliography}

\section{Primary sources}

Anonyme, Hazānat al-Silāh (Khazānat 'Assilāh by "Anonymous Author" Treasure of Arms with a study about the armouries and their contents during the Ayyoubids and Mamluks Periods), ed. Nabill M. ABDEL AzIZ, Cairo, 1978.

Anonyme, Hudūd al- ${ }^{c} \bar{A} l a m$, tr. V. MINORSKY, London, 1937.

Anonyme, The Book of Dede Korkut, tr. G. LEWIS, London, 1974.

Aqsarā̄ì (al-), Muhammad b. 'Īsāà, Kitāb nihāyat al-su'l wa al-Umniyya fì tac allum acmāl al-furūsiyya (facsimile of British Library Ms. Add. 18866), London, 2008.

Bertrandon de la Brocquière, The Voyage d'Outremer by Bertrandon de la Brocquière, tr. G.R. KLINE, New York, 1988.

Enveri, Le Destān d'Umur Pasha, ed. \& tr. I. MÉLIKOFF-SAYAR, Paris, 1954.

Ğāhị (al-), Abū cuțānn 'Amr b. Bahr, "Jāhiz of Basra to Al-Fath ibn Khāqān on the Exploits of the Turks and the Army of the Khalifate in General", tr. C.T. HARLEY-WALKER, Journal of the Royal Asiatic Society, 1915, p. 631-697.

Ğāḥiz (al-), Abū 'Uțmān ${ }^{\mathrm{c} A m r}$ b. Baḥr, Rasā̉il al-Ǧāḥiz, (ed. 'Abd al-Salām Muhammad HĀRūN, Cairo - Baghdad, 1965.

Ibn Hudayl, 'Alī b. 'Abd al-Raḥmān al-Andalusī, Gala de Caballeros, Blasons de Paladines, tr. M.J. VigueRA, Madrid, 1977.

Ibn Hudayl, 'Alī b. 'A Abd al-Raḥmān al-Andalusī, La Parure des Cavaliers et l'Insigne des Preux, tr. L. MERCIER, Paris, 1924.

Ibn Ishāq, Muhammad b. Ya'qūb (attributed to), Munyatu'l-Ghuzāt, a 14th-Century Mamluk-Kipchak Military Treatise. Sources of Oriental Languages and Literatures 13. Turkish Sources XI, ed. \& tr. K. ÖZTOPÇ, Cambridge Mass., 1989.

Ibn Iyās, Muḥammad, Die Chronik des Ibn Iyâs, ed. P. KAHLE \& M. MUSTAFA, Leipzig - Istanbul, 1931.

Ibn Iyās, Muhammad, Journal d'un Bourgeois du Caire, tr. G. WIET, Paris, 1955.

Ibn Kannān, Muhammad b. 'Isā, Yawmìyāt šāmīyah (1111-1153/1699-1740), ed. Akram AL- 'UlABī, Damascus, 1994.

Ibn Manglī al-Nāșirī, Muhammad, Ibn Manglī, De la chasse. Commerce des grands de ce monde avec les bêtes sauvages des déserts sans onde, tr. F. VIRÉ, Paris, 1984.

Ibn Maymūn, Abū Muhammad Ǧamāl al-Dīn cAbd Allāh, Al-Ifāda wa l-tabșīr li-kullī rāmin (see N.A. FARIS, \& R.P. ELMER, 1945, Arab Archery, Princeton).

Jacques de Vitry, Historia Orientalis, ed. BONGARS, Hanover, 1612.

Muhammad b. Manșūr Fahr al-Dīn (Fakhr-i Mudabbir) (also known as Mubārakšāh), "Ādāb al Ḥarb”, tr. E. McEWEN, The Islamic Quarterly 18, 1974, p. 76-99.

Muhammad b. Manșūr Faḩr al-Dīn (also known as Mubārakšāh), Ādāb al-harb wal-šuğăa a, ed. A.S. ȞWĀNSĀRĪ, Tehran, 1969.

Ṭaybuğā al-Ašrafī al-Baklamīš̄̄ al-Yunānī, Saracen Archery. An English Version and Exposition of a Mameluke Work on Archery, tr. J.D. LATHAM \& W.F. PATERSON, London, 1970. 


\section{Secondary sources}

ADAMS W.Y. 1996, Qașr Ibrim: The Late Medieval Period, London.

ALEXANDER D. (et al eds.) 2003, From the Medicis to the Savoias. Ottoman Splendour in Florentine Collections, Istanbul.

Baroudy F., BadWi A., KhaWaja P. and MoukARZel J. 2011, Asi-l-Hadath, Lebanon, History of a Grotto, Jounieh.

BENTOVICH I.B. 1958, "Nakhodki na Gore Mug”, Materiali i Issledovaniya po Arkheologii SSSR 66, p. 358-383.

BOAS A.J. 1999, Crusader Archaeology, The Material Culture of the Latin East, London.

BoIT B.A. 1991, "Building a Better Bow: Technical Refinement of the Turkish Composite Bow during the Crusading Era", unpublished paper, Ohio State University, Ohio.

CARAYON A. 2012, La Furūsiyya des Mamlūks: une élite sociale à cheval (1250-1517), Phd. thesis, Aix-en-Provence.

Clermont-Ganneau C.1901, “The Depository of Ancient Arrows in the Castle of David”, Palestine Exploration Fund Quarterly Statement, p. 136-137.

ÇORUHLU T. 2003, “Osmanli-Türk Kültüründe Savaş ve Sanat”, Savaş ve Sanat 30, Summer, p. 80-95.

CoUlSTON J.C. 1985, "Roman Archery Equipment", in M.C. BISHOP (ed.), The Production and Distribution of Roman Military Equipment (Proceedings of the Second Roman Military Equipment Research Seminar), BAR International Series 275, Oxford, p. 220-366.

DE LuCiA G. 1908, La Sala d'Armi nel'Museo dell'arsenale di Venezia, Rome.

FARIS N.A. and ELMER R.P. 1945, Arab Archery, Princeton ${ }^{8}$ (see Ibn Maymūn, 1945).

GARBSCH J. 1978, Römische Paraderüstungen, Munich.

GAUNT G.D. and A.M. 1973, "Mongol Archers of the Thirteenth Century", Journal of the Society of Archer Antiquaries 16, p. 20-21.

IERUSALIMSKAYA A.A. 2012, Moschevaya Balka, St. Petersburg.

JAMES S. 2004, Excavations at Dura-Europos 1928-1937. Final Report VII, The Arms and Armour and other Military Equipment, London.

KHUDYAKOV Y.S. 1980, Vooruzheniye Eniseiskikh Khirgizov VI-XII vv., Novosibirsk.

KHUDYAKOV Y.S. 1986, Vooruzheniye Srednevekovikh Kochevnikov Yuzhnoi Sibiri, Novosibirsk.

KHUDYAKOV Y.S. 1998, "The Turfan Uigurs' Bows and Arrows", Information Bulletin, issue 21, International Association for the Study of the Cultures of Central Asia, Moscow, p. 91-97.

KLOPSTEG P.E. 1947, Turkish Archery and the Composite Bow, Evanston.

LATHAM J.D. and PATERSON W.F. 1965, "An Analysis of Arrow-Weights in an Islamic Military Manual", Journal of Semitic Studies 10, p. 253-261.

LATHAM J.D. and PATERSON W.F. 1970, Saracen Archery. An English Version and Exposition of a Mameluke Work on Archery, London (see also Ṭaybuḡā al-Ašrafī).

LATHAM J.D. 1968, “The Meaning of 'Maydan as-Sibaq”, Journal of Semitic Studies 13, p. 241-248.

LATHAM J.D. 1969, "Notes on Mamlūk Horse-Archers", Bulletin of the School of Oriental and African Studies 32, p. 257-267.

8. At the time of publication the authors were unaware that the text which they translated had actually been written by Abū Muhammad Ǧamāl al-Dīn cAbd Allāh b. Maymūn in 13th century Morocco. 
MerRIL S. 1906, "Ancient Arrows in the Castle of David", Palestine Exploration Fund Quarterly Statement, p. 106.

MiLlER R. 1985, “Experimental Approaches to Ancient Near Eastern Archery”, unpublished lecture at the Yarmouk University Institute of Archaeology and Anthropology, Jordan, 5 November 1985.

Milovanov E. and JRUSALIMSKAYA A. 1976, "Luk iz Moschevaya Balka (Un arc de sepulcre Mochtchevaja Balka)", Soobshcheniia Gosudarstvennogo ordena Lenina Ermitzha, Bulletin du Musée d'Etat de l'Ermitage 41, p. 40-43.

MORABIA A. 1986, "Lawn [Colour]”, in Encyclopedia of Islam, $2^{\text {nd }}$ edition, vol. 5, Leiden, p. 711.

MouTon J.-M. (ed.) 2010, Șadr, une forteresse de Saladin au Sinaï, Paris.

Nicolle D.C. 2011, Late Mamlūk Military Equipment. Collection Travaux et Études de la Mission Archéologique Syro-Française, Citadelle de Damas (1999-2006), Vol. III, Damascus.

PAILlET J. L. 1983, Le Château de Rahba: Étude d'architecture militaire islamique médiévale, Doctoral thesis, Université de Lyon 2.

PETRASCH E. 1977, Die Türkenbeute, Karlsruhe.

Pirovano C. (ed.) 1985, Venezia e i Turchi, Milan.

RICHARD J. 1979, "Les Causes des victoires mongoles d'après les historiens occidentaux du XIII siècle", Central Asiatic Journal 23, p. 104-117.

SARRAF (AL-) S. 1989, L'archerie mamluke (A.H. 648-923, A.D. 1250-1517), Doctoral thesis, University of ParisSorbonne.

SARRAF (AL-) S. 1996, "Furūsiyya Lit erat ure of the Maml ūk Period", in D. AleXANDER (ed.), Furūsiyya. Volume I, The Horse in the Art of the Near East, Riyadh, p. 118-135.

SEMENOV S. and KiLUnOVSKAYA M. 1990, "New Archaeological Material of the Early Iron Age from Tuva", Information Bulletin, issue 17, International Association for the Study of the Cultures of Central Asia, Moscow, p. 44-56.

SMITH J.M. 1996, "Mongol Society and Military in the Middle East; Antecedents and Adaptations", in Y. LEV (ed.), War and Society in the Eastern Mediterranean, 7th-15th Centuries, Leiden, p. 249-266.

SMITH J.M. 2000, “The Nomads' Armament: Home Made Weapons”, in M. GERVERS \& W. SCHLEPP (eds.), Religion, Customary Law, and Nomadic Technology, Toronto, p. 51-61.

STEIN M.A. 1921, Serindia, Oxford.

STEIN M.A. 1928, Innermost Asia, Oxford.

T'AN TAN-CHIUNG 1981, "Investigative Report on Bow and Arrow Manufacturing in Chengtu", originally published the Soochow University Journal of Chinese Art History 11, July, p. 143-216.

URAY-KÖHALMi K. 1968, “Two Saddle Finds from Western Mongolis”, Acta Archaeologica Academiae Scientiarum Hungaricae 20, p. 347-358.

ZOUACHE A. 2010, "Les armes et le matériel à usage militaire", in J.-M. MouTON (éd.), Șadr, une forteresse de Saladin au Sinaï, Paris, p. 35-69. 